\title{
Fluid geochemistry of a deep-seated geothermal resource in the Puna plateau (Jujuy Province, Argentina)
}

\author{
Y. Peralta Arnold ${ }^{\text {a }}$, J. Cabassi b,c, F. Tassi ${ }^{\text {b,c, }}$, P.J. Caffe ${ }^{\text {a }}$, O. Vaselli ${ }^{\text {b,c }}$ \\ a Instituto de Ecorregiones Andinas (INECOA), Universidad Nacional de Jujuy-CONICET, Instituto de Geología y Minería, Av. Bolivia 1661, San Salvador de Jujuy CP 4600, Jujuy, Argentina \\ b Department of Earth Sciences, University of Florence, Via La Pira 4, 50121 Firenze, Italy \\ c CNR-IGG Institute of Geosciences and Earth Resources, Via La Pira 4, 50121 Firenze, Italy
}

\section{A R T I C L E I N F O}

\section{Article history:}

Received 20 December 2016

Received in revised form 27 March 2017

Accepted 28 March 2017

Available online 2 April 2017

\section{Keywords:}

Thermal spring

Fluid geochemistry

Hydrothermal fluid

Northern Puna

Jujuy Province

\begin{abstract}
A B S T R A C T
This study focused on the geochemical and isotopic features of thermal fluids discharged from five zones located in the high altitude Puna plateau (Jujuy Province between S $22^{\circ} 20^{\prime}-23^{\circ} 20^{\prime}$ and $\mathrm{W} 66^{\circ}-67^{\circ}$ ), i.e. Granada, Vilama, Pairique, Coranzulí and Olaroz. Partially mature waters with a $\mathrm{Na}^{+}-\mathrm{Cl}^{-}$composition were recognized in all the investigated zones, suggesting that a deep hydrothermal reservoir hosted within the Paleozoic crystalline basement represents the main hydrothermal fluid source. The hydrothermal reservoirs are mainly recharged by meteoric water, although based on the $\delta^{18} \mathrm{O}-\mathrm{H}_{2} \mathrm{O}$ and $\delta \mathrm{D}-\mathrm{H}_{2} \mathrm{O}$ values, some contribution of andesitic water cannot be completely ruled out. Regional S-oriented faulting systems, which generated a horst and graben tectonics, and NE-, NW- and WE-oriented transverse structures, likely act as preferentially uprising pathways for the deep-originated fluids, as also supported by the Rc/Ra values (up to 1.39) indicating the occurrence of significant amounts of mantle He (up to 16\%). Carbon dioxide, the most abundant compound in the gas phase associated with the thermal waters, mostly originated from a crustal source, although the occurrence of $\mathrm{CO}_{2}$ from a mantle source, contaminated by organic-rich material due to the subduction process, is also possible. Relatively small and cold $\mathrm{Na}^{+}-\mathrm{HCO}_{3}^{-}$-type aquifers were produced by the interaction between meteoric water and Cretaceous, Palaeogene to Miocene sediments. Dissolution of evaporitic surficial deposits strongly affected the chemistry of the thermal springs in the peripheral zones of the study area. Geothermometry in the Na-K-Ca-Mg system suggested equilibrium temperatures up to $200{ }^{\circ} \mathrm{C}$ for the deep aquifer, whereas lower temperatures (from 105 to $155{ }^{\circ} \mathrm{C}$ ) were inferred by applying the $\mathrm{H}_{2}$ geothermometer, likely due to re-equilibrium processes during the thermal fluid uprising within relatively shallow $\mathrm{Na}-\mathrm{HCO}_{3}$ aquifers. The great depth of the geothermal resource (possibly $>5000 \mathrm{~m}$ b.g.l.) is likely preventing further studies aimed to evaluate possible exploitation, although the occurrence of Liand Ba-rich deposits associated may attract financial investments, giving a pulse for the development of this remote region.
\end{abstract}

(C) 2017 Elsevier B.V. All rights reserved.

\section{Introduction}

The western sector of the Jujuy Province (NW Argentina) is part of northern Puna, a high-altitude plateau (from 3000 to $5000 \mathrm{~m}$ a.s.l.) that borders the Central Volcanic Zone (CVZ). Miocene-Pliocene volcanic complexes and extensive ignimbrite plateaus dominate the region that is characterized by arid climate and internally draining basins producing extended salt deposits (salar) and ephemeral B- and Li-rich salt lakes. Neogene volcanogenic polymetallic ( $\mathrm{Ag}, \mathrm{Pb}, \mathrm{Zn}, \mathrm{Sn}$ ) sulfide ore deposits (some of them of world class) are also occurring, mostly being exploited by private and governmental companies (Lopez Steinmetz, 2016). Coira (2008) and Pesce (2008) reported the occurrence of several thermal fluids discharges in northern Puna, although little is known

\footnotetext{
* Corresponding author.

E-mail address: franco.tassi@unifi.it (F. Tassi).
}

about their chemical and isotopic features. Few geochemical data (temperature outlets and concentrations of the main solutes) were produced in the framework of geochemical prospection surveys carried out in the 1970 's and 1990's by different companies: 1) Aquater Ltd., in collaboration with the Jujuy Mining Direction and Mining Secretary, Hidroproyectos SA, Setec SRL, and Cepic SC; 2) Jujuy Government, in collaboration with CREGEN and Universidad Nacional de Jujuy. According to these preliminary data, the geothermal potential in this area was considered of interest for a possible exploitation. Notwithstanding these promising results, the activity stopped after the drilling of few explorative, unproductive wells at Tuzgle-Tocomar zone (Giordano et al., 2013). The recent renewed interest for geothermal energy (Argentine National Laws n. 26.190/06 and n. 27.191/15), as well as the exploitation of other natural resources such as Li-rich deposits (Lopez Steinmetz, 2016), has intensified investigations in northern Puna aimed to evaluate, by means of geochemical and isotopic tools, the occurrence of 
thermal fluid reservoirs and their suitability for an exploitation in the years to come.

In this paper, original set of chemical and isotopic data of thermal fluid discharges from an area of $8000 \mathrm{~km}^{2}$ in the Puna plateau, comprised between $S 22^{\circ} 20^{\prime}-23^{\circ} 20^{\prime}$ and $\mathrm{W} 66^{\circ}-67^{\circ}$ (Fig. 1 ), are presented. To provide insights into the potential geothermal resource, the main goals are to 1) describe the geochemical and isotopic features of waters and gases, and 2) investigate the primary fluid sources and the secondary processes controlling the fluid chemistry as fluids are discharged to the surface.

\section{Geological and volcanological settings}

The Puna plateau is located in the back-arc area of CVZ, where the subduction of the Nazca Plate beneath that of South America takes place (Allmendinger et al., 1997 and references therein). A seismic anomaly in the middle crust, between $22^{\circ} \mathrm{S}$ and $24.5^{\circ} \mathrm{S}$, was interpreted as related to the presence of a $\sim 1 \mathrm{~km}$ thick sill-like igneous body, namely Altiplano Puna Magmatic Body (APMB) (Chmielowski et al., 1999; Zandt et al., 2003; Ward et al., 2014). As shown in Fig. 1a,b, the outcropping basement formations consist of Ordovician shallow-marine

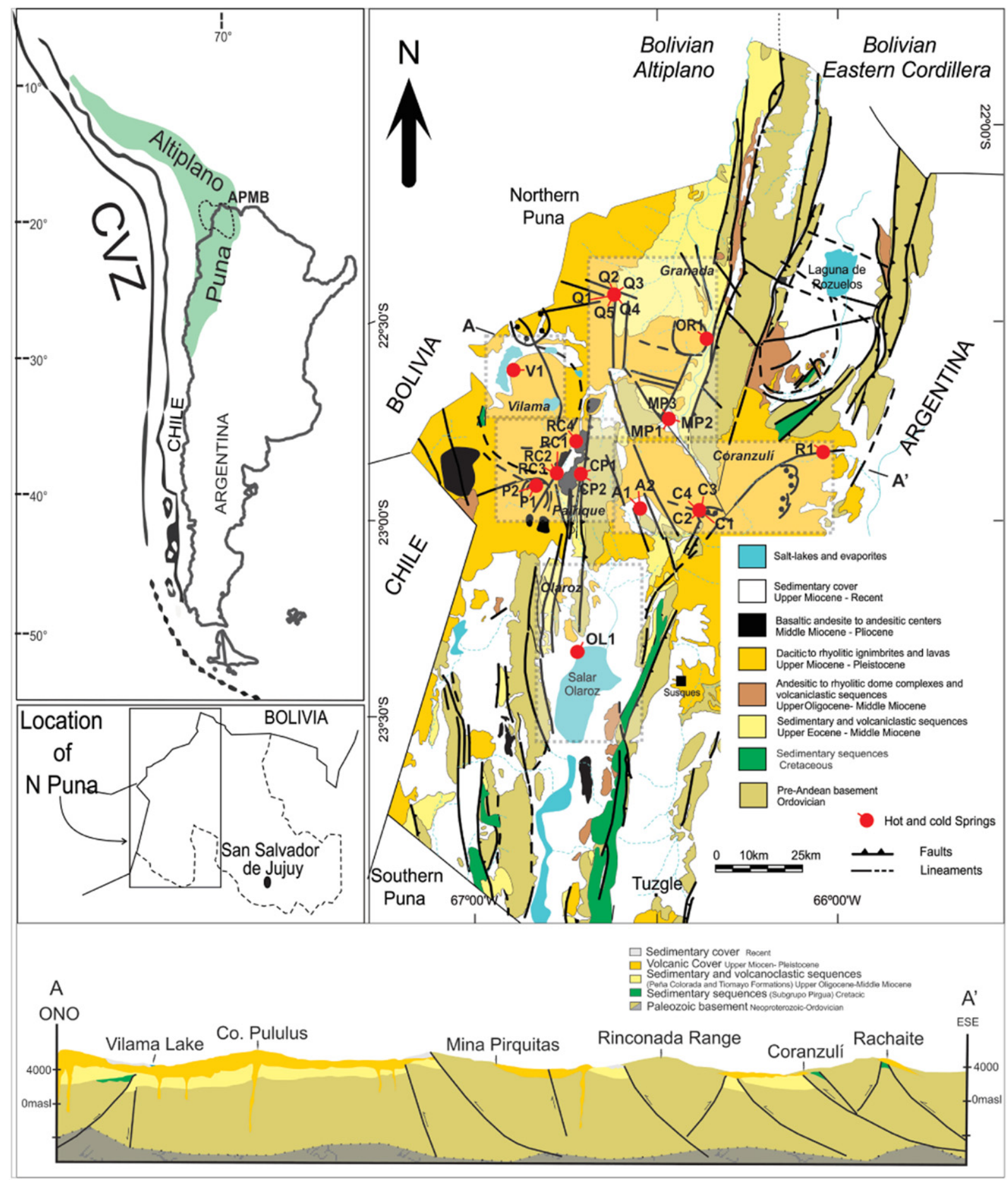

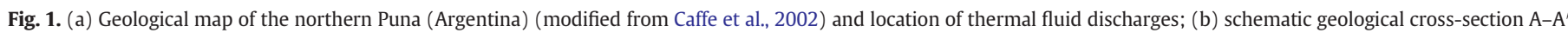
(modified from Coira et al., 2004). 
sandstones and deep-marine turbidites (Bahlburg, 1998), which in some areas (e.g., Quichagua, Escaya, Huancar) are intercalated with volcaniclastic and submarine lavas and cryptodomes (Coira and Caffe, 1999; Coira and Pérez, 2002). This sequence overlay Cambrian sandstones (Meson Group) and Neoproterozoic-Cambrian low-grade metamorphic rocks cropping out in the Cordillera Oriental (E of the study area). The Ordovician sequence is covered by Cretaceous to Early Eocene continental and littoral sedimentary deposits of the Salta Subgroup (Marquillas et al., 2005). Palaeogene to Lower Miocene continental conglomerates with intercalations of calcareous sandstones, namely Peña Colorada and Vizcachera Formations (Coira et al., 2004), uncomformably cover the Salta Group sediments. Middle Miocene to Pliocene volcano-sedimentary rocks, which include fluvial to lacustrine deposits (Tiomayo and Sijes Formations) and fluvial-alluvial deposits (Pastos Chicos-Trinchera Formations) (Coira et al., 2004), close the geological sequence.

Volcanic activity in Oligocene-Miocene (22-18 Ma) produced pyroclastic sequences interstratified with continental sedimentary deposits (Caffe et al., 2002; del Papa et al., 2013), followed by the emplacement of sub-volcanic bodies ( 12 Ma) (Coira et al., 1993; Caffe et al., 2002) and a period of intense volcanism (between 8.5 and $4 \mathrm{Ma}$; Kay et al., 2010). During the Neogene, giant calderas were produced and huge ignimbrite deposits $\left(\sim 11-15 \times 10^{3} \mathrm{~km}^{3}\right.$; Kay et al., 2010; Salisbury et al., 2011) formed the Altiplano Puna Volcanic Complex (APVC; de Silva, 1989; de Silva et al., 2006). The recent sedimentary deposits consist of clastic and detrital material, alluvial fans and evaporitic deposits (Alonso, 1999).

Since the Eocene, crustal shortening dominated this region (Allmendinger et al., 1997; Coutand et al., 2001), causing extensive reverse and deep regional faulting that generated a NS-aligned horst and graben series. NE-, NW- and W-E-oriented transverse structures acted as preferential pathways for magma ascent during the Upper Miocene (Petrinovic et al., 2006).

The climate in Northern Puna is dominantly arid, being controlled by the South American Monsoon System (Garreaud, 2009; Garreaud et al., 2010). The ruling drainage is endorheic and originates extended salt deposits and salt lakes, such as the Guayatayoc Lake, Salinas Grandes salt pans, the Cauchari-Olaroz saline system and Lake Vilama.

The study area includes 5 zones characterized by the occurrence of thermal springs and distinctive geological characteristics: Granada, Vilama, Pairique, Coranzulí, and Olaroz.

\subsection{Granada}

The Abra Granada Volcanic Complex (AGVC), built from 9 to $5 \mathrm{Ma}$, consists of lavas, ignimbrites and block-and-ash deposits erupted from Cerro Caucani, Solterío and Granada volcanoes (Ramírez, 1997; Coira et al., 2004). The AGVC rocks are laying on, as follows (Caffe et al., 2008; Coira et al., 2004 and references therein): 1) Ordovician basement, consisting of sandstones and mudstones (Acoite Formation); 2) Paleogene to Lower Miocene continental red beds (Peña Colorada Formation) and Middle Miocene fluvial-lacustrine deposits (Tiomayo Formation); 3) Upper Miocene volcanic units including the Orosmayo (10.3 Ma), Lagunillas (10.2 Ma) and Granada ignimbrites ( 9.8 Ma). Primary polymetallic sulfide ore deposits of Sn-Ag-Zn and Sn-Au (Soler et al., 2008) are exploited from the Mina Pirquitas mining district nearby AGVC.

\subsection{Vilama}

This zone shows extensive pyroclastic deposits originated from the Vilama caldera, a large volcanic structure $(40 \times 15 \mathrm{~km})$ that first erupted 8.5 Ma (Soler et al., 2007). The Salle, Khastor and Bayo volcanoes were emplaced over the inferred ring fault of the caldera. The Vilama caldera is laying on the Ordovician basement, Cretaceous sedimentary rocks and older volcanic deposits (Soler et al., 2007; Caffe et al., 2008). After the caldera collapse, resurgence episodes produced ignimbrites, lavas and domes (Soler et al., 2007; Fracchia, 2009).

\subsection{Pairique}

The Ordovician sedimentary basement rocks (Fig. 1a,b), cropping out at Sierra de Lina and Sierra de Olaroz, are covered by Paleogene to Lower Miocene red bed sandstones and mudstones pertaining to Peña Colorada Formation (Coira et al., 2004). Rhyolites ( 10-11 Ma) pertaining to the Pairique Volcanic Complex (Caffe et al., 2007), and Cerro Morado basaltic-andesite $(6.7 \pm 0.4 \mathrm{Ma})$ were also recognized (Coira et al., 1996; Cabrera and Caffe, 2009).

\subsection{Coranzulí}

The main geological structure of Coranzulì is the Upper Miocene Coranzulí Volcanic Complex (CVC) that is a collapsed caldera located at the intersection between the NW-SE Coyaguayma and the NE-SW Rachaite lineaments. The stratigraphic sequence also includes, from the bottom to the top (Seggiaro et al., 2014): 1) Neoproterozoic-Ordovician basement and Cenozoic continental sediments and volcaniclastic rocks (equivalent to Vizcachera and Tiomayo Formations) overlain by crystal-rich and peraluminous dacitic to rhyodacitic ignimbrites; 2) pre-collapse Rachaite stratovolcano (7.2-8.4 Ma; Heidorn, 2002), located $\sim 25 \mathrm{~km} \mathrm{NE}$ of the CVC, a dacitic-to-andesitic central edifice consisting of pyroclastic deposits (Doncellas Formation), andesitic lavas and breccias (Coira et al., 2008); 3) ignimbrites and related breccia facies, as well as pyroclastic surges interstratified with alluvial deposits (Morro Grande and Loma Blanca Formations; Alonso, 1986); 4) collapse products ( 6.7 Ma), namely Abra Grande, Potreros, Las Termas and Corral de Sangre ignimbrites; 5) Cerro Coranzulí dome lavas (6.2 Ma).

\subsection{Olaroz}

A $\sim 160 \mathrm{~km}^{2}$ wide salar covers most of this area. The sedimentary deposits are mainly consisting of (i) Ordovician turbidites associated with granitic to granodioritic bodies (the Tanque Intrusive Complex, Coira et al., 2009), (ii) Upper Cretaceous fluvial deposits (Pirgua Subgroup). Ignimbritic deposits from the CVC and the Coyaguayma volcano (Seggiaro et al., 2014) form the main lithologies of the most prominent ranges (Fig. 1). The stratigraphic sequence also includes 1) limestone, shale and sandstone sequences belonging to the Lecho and Yacoraite formations, 2) Paleogene sandstones and conglomerates (Santa Bárbara Subgroup), and 3) Neogene conglomeratic fluvial sediments (Vizcachera Formation) and lacustrine evaporites with interbedded volcanoclastic deposits (Sijes Formation) (Seggiaro et al., 2007).

\section{Materials and methods}

\subsection{Water and gas sampling}

Water samples from 23 thermal discharges and 3 creeks (C) and free and dissolved gas samples from 13 bubbling pools and 11 thermal springs, respectively, were collected from the five studied zones (Fig. 1). At Granada (Fig. 1a), fluid discharges occur in 3 sites, as follows: 1) Queñual (Q1 to Q5), located NW of Cerro Granada in a ravine cutting Ordovician rocks; 2) Mina Pirquitas (MP1 to MP3), emerging from travertine cones covering Peña Colorada Formation, $5 \mathrm{~km}$ SE of the mine property; 3 ) Orosmayo (OR1), located NE of Cerro Granada and emerging at the contact between the Tiomayo Formation and a mineralized (Mo) dacitic intrusion pertaining to the Orosmayo-Cerro Colorado Volcanic Complex (Rodriguez, 1997). At Vilama (Fig. 1a), only one thermal spring (V1), located at the border of the salty Lake Vilama, was found. Differently, Pairique hosts 3 groups of thermal springs (Fig. 1a), as follows: 1) Pairique (P1 and P2), emerging from the Bajo Pairique lavas, i.e. the oldest rocks of the whole volcanic complex (Caffe et al., 2007); 


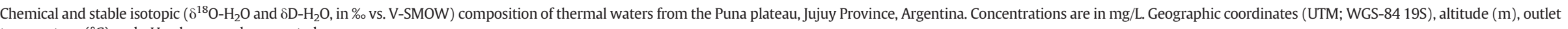
temperature $\left({ }^{\circ} \mathrm{C}\right)$ and $\mathrm{pH}$ values are also reported.

\begin{tabular}{|c|c|c|c|c|c|c|c|c|c|c|c|c|c|c|c|c|c|c|c|c|c|c|c|}
\hline & id & Type & Zone & Altitude & $\mathrm{T}$ & $\mathrm{pH}$ & $\mathrm{HCO}_{3}{ }^{-}$ & $\mathrm{F}^{-}$ & $\mathrm{Cl}^{-}$ & $\mathrm{Br}^{-}$ & $\mathrm{NO}_{3}{ }^{-}$ & $\mathrm{SO}_{4}^{2-}$ & $\mathrm{Ca}^{2+}$ & $\mathrm{Mg}^{2+}$ & $\mathrm{Na}^{+}$ & $\mathrm{K}^{+}$ & $\mathrm{NH}_{4}{ }^{+}$ & $\mathrm{Li}^{+}$ & $\mathrm{SiO}_{2}$ & B & TDS & $\delta^{18} \mathrm{O}$ & $\delta \mathrm{D}$ \\
\hline Olaroz 1 & 01 & TS & Olaroz & 3905 & 22.1 & 7.40 & 2750 & 17 & 177,700 & 83 & 21 & 7860 & 1090 & 4780 & 115,900 & 4380 & 21 & 602 & 49 & 558 & 315,810 & -1.3 & -78 \\
\hline Vilama 1 & V1 & TS & Vilama & 4500 & 27.9 & 5.92 & 1010 & 2.1 & 20,800 & 15 & 1.1 & 1680 & 1250 & 905 & 11,800 & 765 & 12 & 126 & 87 & 133 & 38,587 & -2.4 & -72 \\
\hline Rosario Coyaguayma 1 & RC1 & TS & Pairique & 4161 & 59.8 & 6.74 & 1300 & 2.0 & 4020 & 6.6 & 0.35 & 463 & 183 & 33 & 3190 & 209 & 8.0 & 29 & 169 & 31 & 9643 & -3.2 & -74 \\
\hline Rosario Coyaguayma 2 & RC2 & TS & Pairique & 4317 & 58.6 & 6.70 & 1290 & 0.67 & 3670 & 5.7 & 2.5 & 399 & 163 & 31 & 3014 & 191 & 9.4 & 26 & 156 & 26 & 8984 & -3.5 & -71 \\
\hline Rosario Coyaguayma 3 & RC3 & TS & Pairique & 4308 & 62.4 & 6.64 & 1250 & 0.71 & 3930 & 7.7 & 0.37 & 430 & 181 & 32 & 3150 & 215 & 6.7 & 29 & 158 & 33 & 9423 & -2.9 & -69 \\
\hline Rosario Coyaguayma 4 & RC4 & C & Pairique & 4457 & 17.8 & 8.65 & 130 & 0.20 & 9.3 & 0.03 & 1.0 & 34 & 26 & 6.3 & 19 & 5.9 & 1.0 & 0.06 & 21 & & 254 & -11.6 & -85 \\
\hline Cono Panizo 1 & $\mathrm{CP} 1$ & TS & Pairique & 4420 & 34.8 & 6.61 & 1710 & 2.1 & 2570 & 6.1 & 6.2 & 53 & 154 & 52 & 1930 & 170 & 7.7 & 20 & 137 & 16 & 6834 & -9.7 & -75 \\
\hline Cono Panizo 2 & $\mathrm{CP} 2$ & TS & Pairique & 4410 & 43.2 & 7.07 & 1530 & 2.2 & 2540 & 4.9 & 4.5 & 52 & 137 & 57 & 1900 & 124 & 6.6 & 19 & 144 & 19 & 6540 & -9.8 & -76 \\
\hline Pairique 1 & P1 & TS & Pairique & 4303 & 44.2 & 7.10 & 643 & 0.31 & 345 & 1.5 & 1.0 & 126 & 11 & 5.0 & 499 & 9.1 & 0.80 & 0.49 & 109 & 2.1 & 1755 & -8.9 & -61 \\
\hline Pairique 2 & P2 & TS & Pairique & 4299 & 43.5 & 7.02 & 572 & 0.43 & 352 & 1.7 & 0.12 & 121 & 11 & 5.0 & 478 & 8.0 & 0.87 & 0.47 & 111 & 2.2 & 1663 & -9.5 & -65 \\
\hline Arituzar 1 & A1 & TS & Coranzuli & 4134 & 19.7 & 5.96 & 2900 & 14.0 & 25,900 & 16 & 35 & 338 & 399 & 573 & 14,500 & 1090 & 180 & 306 & 115 & 178 & 46,544 & -2.3 & -70 \\
\hline Arituzar 2 & A2 & TS & Coranzuli & 4134 & 18.6 & 6.67 & 2140 & 6.8 & 19,300 & 13 & 19 & 342 & 457 & 681 & 10,300 & 690 & 90 & 206 & 107 & 156 & 34,508 & -2.1 & -68 \\
\hline Coranzuli 1 & $\mathrm{C} 1$ & TS & Coranzuli & 4131 & 31.0 & 8.40 & 390 & 0.51 & 99 & 0.24 & 1.2 & 25 & 22 & 3.1 & 183 & 4.0 & 2.0 & 0.39 & 79 & 0.56 & 810 & -12.8 & -94 \\
\hline Coranzuli 2 & $\mathrm{C} 2$ & TS & Coranzuli & 4134 & 32.5 & 7.28 & 397 & 0.51 & 96 & 0.22 & 1.2 & 24 & 22 & 3.2 & 179 & 3.9 & 2.0 & 0.43 & 85 & 0.74 & 816 & -12.8 & -94 \\
\hline Coranzuli 3 & C3 & TS & Coranzuli & 4136 & 27.2 & 7.52 & 393 & 0.61 & 97 & 0.23 & 1.3 & 25 & 27 & 4.0 & 183 & 3.7 & 2.1 & 0.45 & 74 & 0.78 & 812 & -12.8 & -94 \\
\hline Coranzuli 4 & C4 & C & Coranzuli & 4145 & 18.1 & 4.84 & 9.0 & 0.88 & 6.6 & 0.03 & 0.30 & 314 & 93 & 13 & 19 & 8.6 & 1.5 & 0.04 & 16 & 0.22 & 482 & -10.1 & -75 \\
\hline Rachaite 1 & R1 & TS & Coranzuli & 3620 & 22.3 & 7.02 & 115 & 0.17 & 12 & 0.07 & 5.3 & 27 & 23 & 5.8 & 15 & 10.8 & 1.2 & 0.07 & 49 & 0.18 & 264 & -11.4 & -83 \\
\hline Mina Pirquitas 1 & MP1 & TS & Granada & 4106 & 22.0 & 6.32 & 2820 & 6.3 & 9030 & 18 & 2.6 & 431 & 364 & 137 & 5570 & 202 & 51 & 67 & 56 & 61 & 18,815 & -1.4 & -68 \\
\hline Mina Pirquitas 2 & MP2 & TS & Granada & 4106 & 16.7 & 6.46 & 3230 & 3.2 & 10,100 & 22 & 6.5 & 427 & 373 & 155 & 6620 & 243 & 59 & 81 & 62 & 85 & 21,466 & -1.3 & -66 \\
\hline Mina Pirquitas 3 & MP3 & C & Granada & 4094 & 11.7 & 7.73 & 1970 & 3.4 & 6240 & 12 & 41 & 359 & 234 & 104 & 3930 & 152 & 27 & 54 & 57 & 66 & 13,250 & -1.9 & -72 \\
\hline Queñual 1 & Q1 & TS & Granada & 3928 & 29.0 & 6.38 & 569 & 12.6 & 790 & 1.4 & 12 & 162 & 91 & 32 & 617 & 20 & 3.7 & 4.0 & 77 & 3.5 & 2395 & -9.3 & -75 \\
\hline Queñual 2 & Q2 & TS & Granada & 3913 & 50.5 & 7.62 & 1170 & 10.5 & 2310 & 3.0 & 5.2 & 131 & 118 & 29 & 1740 & 55 & 8.8 & 10 & 163 & 35 & 5788 & -8.5 & -73 \\
\hline Queñual 3 & Q3 & TS & Granada & 3907 & 47.1 & 6.50 & 1240 & 2.1 & 3030 & 4.7 & 42 & 57 & 147 & 40 & 2260 & 99 & 18 & 15 & 169 & 46 & 7170 & -8.1 & -74 \\
\hline Queñual 4 & Q4 & TS & Granada & 3887 & 45.6 & 6.68 & 1390 & 4.8 & 4070 & 5.6 & 1.5 & 30 & 210 & 55 & 2510 & 81 & 11 & 15 & 151 & 55 & 8590 & -7.8 & -75 \\
\hline Queñual 5 & Q5 & TS & Granada & 3895 & 43.3 & 7.15 & 1390 & 5.3 & 3730 & 5.9 & 1.2 & 54 & 109 & 36 & 2820 & 110 & 12 & 16 & 154 & 51 & 8495 & -8.1 & -72 \\
\hline \multirow[t]{4}{*}{ Orosmayo 1} & OR1 & TS & Granada & 3989 & 24.3 & 8.37 & 356 & 0.11 & 17 & 0.04 & 0.26 & 21 & 13 & 3.9 & 119 & 1.3 & 0.62 & 0.13 & 55 & 0.63 & 587 & -12.1 & -90 \\
\hline & MW1 & MW & & 2040 & & & & & & & & & & & & & & & & & & -7.8 & -53 \\
\hline & MW2 & MW & & 1227 & & & & & & & & & & & & & & & & & & -5.7 & -35 \\
\hline & MW3 & MW & & 1328 & & & & & & & & & & & & & & & & & & -5.9 & -38 \\
\hline
\end{tabular}


2) Rosario de Coyaguayma (RC1 to RC5), emerging in correspondence of a NE dextral-strike-slip fault, where a travertine platform, altered dacitic lavas (Brecha Morada), and hydrothermalized terrains occur (Caffe et al., 2005, 2007); 3) Cono Panizo (CP1 and CP2), located 8 km E of Rosario de Coyaguayma emerge from a travertine mound in correspondence of a reverse fault cutting the Ordovician rocks (Sierra de Lina). Three groups of thermal springs were also recognized at Coranzuli (Fig. 1a), as follows: 1) Coranzulí ( $\mathrm{C} 1$ to $\mathrm{C} 4$ from where abundant travertine is precipitating above Las Termas ignimbrite deposits; 2) Arituzar (A1 and A2), $15 \mathrm{~km} \mathrm{~W}$ of Coranzulí, discharging from two travertine-borate cones covering the Ordovician rocks; 3 ) Rachaite (R1), a thermal spring emerging along a creek in correspondence of the basal ignimbrites deposited from the Rachaite volcano and belonging to the Doncellas Formation. Eventually, the Olaroz springs (01) discharge from a salt crust in the northern sector of the salar (Fig. 1a).

Since the average annual temperatures range from 5 to $9{ }^{\circ} \mathrm{C}$, the fluid discharges can be classified as thermal springs (TS), the lowest outlet temperatures being from 16 to $20^{\circ} \mathrm{C}$ (Table 1). Three rainwater samples (RW1, 2, and 3; Table 1) were collected at 2040, 1227 to $1328 \mathrm{~m}$ a.s.l., respectively, and analyzed for oxygen and hydrogen isotopes. Water temperature and $\mathrm{pH}$ were measured in situ. Four aliquots (1 filtered and 2 filtered-acidified, with ultrapure $\mathrm{HCl}$ and $\mathrm{HNO}_{3}$, at $0.45 \mu \mathrm{m}$, and 1 unfiltered for the analysis of anions, cations, trace species, and water isotopes, respectively) were collected from each site. In addition, $25 \mathrm{~mL}$ of water diluted $(1: 10)$ in situ was collected for the analysis of $\mathrm{SiO}_{2}$.

The analysis of dissolved gases was carried out in water samples collected using $50 \mathrm{~mL}$ glass flasks equipped with a rubber septum. In the laboratory, a $10 \mathrm{~cm}^{3}$ headspace was created in the flasks by injecting $\mathrm{H}_{2}$ through the septum. Following a modified method based on Chiodini (1996), the chemical composition was computed by considering the measured concentrations of gases stored in the headspace on the basis of: i) headspace gas pressure and volume, ii) volume of water in the flask and iii) solubility coefficients of each gas compound (Whitfield, 1978). Bubbling gases were sampled using a plastic funnel up-side-down positioned above the pools and connected through tygon tubes to pre-evacuated $50 \mathrm{~mL}$ glass flasks equipped with a Thorion ${ }^{\circledR}$ valve and filled with $20 \mathrm{~mL}$ of $\mathrm{NaOH} 4 \mathrm{M}$ solution (Vaselli et al., 2006). At each bubbling pool, a gas aliquot was also collected in pre-evacuated $80 \mathrm{~mL}$ glass flasks for the analysis of the carbon isotopic ratio in $\mathrm{CO}_{2}\left(\delta^{13} \mathrm{C}-\mathrm{CO}_{2}\right)$.

\subsection{Chemical and isotopic analyses of waters}

Total alkalinity was analyzed by acidimetric titration (AC) using $\mathrm{HCl}$ $0.01 \mathrm{~N}$. Fluoride, $\mathrm{Cl}^{-}, \mathrm{Br}^{-}, \mathrm{NO}_{3}^{-}$and $\mathrm{SO}_{4}^{2-}$ and, $\mathrm{Ca}^{2+}, \mathrm{Mg}^{2+}, \mathrm{Na}^{+}, \mathrm{K}^{+}$, $\mathrm{NH}_{4}^{+}$and $\mathrm{Li}^{+}$were determined by ion-chromatography (IC) using Metrohm 761 and Metrohm 861 chromatographs, respectively. The analytical errors for $\mathrm{AC}$ and IC were $\leq 5 \% . \mathrm{SiO}_{2}$ was analyzed by spectrophotometry (SP) after the addition of a $10 \%(w / v)$ ammonia molybdate solution in a sulfuric acid environment (Bencini and Martini, 1979), while B was analyzed using the Azomethine-H (AH) method (Bencini, 1985) by MS (Philips UNICAM). The analytical errors for SP and AH were $\leq 5 \%$. Trace elements ( $\mathrm{Mn}, \mathrm{Fe}, \mathrm{Co}, \mathrm{Ni}, \mathrm{Cu}, \mathrm{Zn}, \mathrm{Ba}, \mathrm{As}$, and $\mathrm{Sb}$ ) were analyzed by Inductively Coupled Plasma Optical Emission Spectrometry (ICP-OES) using an Optima 8000 Perkin Elmer spectrometer. The analytical error for ICP-OES was $\leq 10 \%$.

The ${ }^{18} \mathrm{O} /{ }^{16} \mathrm{O}$ and ${ }^{2} \mathrm{H} /{ }^{1} \mathrm{H}$ ratios in water (expressed as $\delta^{18} \mathrm{O}-\mathrm{H}_{2} \mathrm{O}$ and $\delta \mathrm{D}-\mathrm{H}_{2} \mathrm{O} \%$ 。s. V-SMOW, respectively) were determined by using a Finnigan Delta Plus XL mass spectrometer at the Geokarst Engineering Laboratory (Trieste, Italy). Oxygen isotopic ratios were analyzed in $\mathrm{CO}_{2}$ added to the water samples using the $\mathrm{CO}_{2}-\mathrm{H}_{2} \mathrm{O}$ equilibration method proposed by Epstein and Mayeda (1953). Hydrogen isotopic ratios were measured on $\mathrm{H}_{2}$ generated by the reaction of $10 \mu \mathrm{L}$ water with metallic zinc at $500{ }^{\circ} \mathrm{C}$ (Coleman et al., 1982). The analytical uncertainties for $\delta^{18} \mathrm{O}-\mathrm{H}_{2} \mathrm{O}$ and $\delta \mathrm{D}-\mathrm{H}_{2} \mathrm{O}$ were $\pm 0.1 \%$ ond $\pm 1.1 \%$, respectively, using V-SMOW and SLAP and AR-1 as international and internal standards, respectively.

\subsection{Chemical and isotopic analysis of dissolved and bubbling gases}

The analysis of $\mathrm{N}_{2},\left(\mathrm{Ar}+\mathrm{O}_{2}\right), \mathrm{H}_{2}$ and $\mathrm{He}$ in the headspace of the soda flasks, as well as those of $\mathrm{CO}_{2}, \mathrm{~N}_{2},\left(\mathrm{Ar}+\mathrm{O}_{2}\right)$, and He in the headspace of the flasks used to sample the dissolved gases, was carried out by gas chromatography (GC) using a Shimadzu 15A instrument equipped with a Thermal Conductivity Detector (TCD). Argon and $\mathrm{O}_{2}$ were analyzed using a Thermo Focus gas chromatograph equipped with a $30 \mathrm{~m}$ long capillary molecular sieve column and a TCD. Methane (in both dissolved and bubbling gases) and light hydrocarbons (in bubbling gases) were determined by using a Shimadzu 14A gas chromatograph equipped with a Flame Ionization Detector (FID) and a $10 \mathrm{~m}$ long stainless steel column packed with Chromosorb PAW 80/100 mesh coated with 23\% SP 1700 (Vaselli et al., 2006). The analytical error for the GC analysis was $\leq 10 \%$. Carbon dioxide (as $\mathrm{CO}_{3}^{2-}$ ) and $\mathrm{H}_{2} \mathrm{~S}$ (as $\mathrm{SO}_{4}^{2-}$ after oxidation with $\mathrm{H}_{2} \mathrm{O}_{2}$ ) were measured in the soda solution by acidimetric titration (using $\mathrm{HCl} 0.1 \mathrm{~N}$ ) and by IC, respectively.

The concentrations (in $\mathrm{mmol} / \mathrm{mol}$ ) of the dissolved gases was given by the sum of $\mathrm{n}_{\mathrm{i}, \mathrm{g}}$ and $\mathrm{n}_{\mathrm{i}, \mathrm{l}}$, which are the moles of the gas compound $i$ in the gas and the liquid portion of the sampling flasks respectively. The $\mathrm{n}_{\mathrm{i}, \mathrm{g}}$ values were computed on the basis of the GC analysis of the gases stored in the sampling flask headspace, whereas the $\mathrm{n}_{\mathrm{i}, 1}$ values were calculated from the $n_{i, g}$ ones by means of the Henry's law constants (Wilhelm et al., 1977), assuming that in the sampling flasks the separated gas phase was in equilibrium with the liquid. The partial pressures of each gas species (in mbar) were then computed, based on the total mole values according to the ideal gas law.

The $\delta^{13} \mathrm{C}-\mathrm{CO}_{2}$ values of both bubbling and dissolved gases were determined by using a Finnigan Delta $\mathrm{S}$ mass spectrometer (MS), after extracting and purifying $\mathrm{CO}_{2}$ by using liquid $\mathrm{N}_{2}$ and $\mathrm{N}_{2}$-trichloroethylene cryogenic traps (Evans et al., 1998; Vaselli et al., 2006). Internal (Carrara and S. Vincenzo marbles) and international (NB18 and NBS19) standards were used for estimating the external precision. Analytical uncertainty and the reproducibility were $\pm 0.05 \%$ ond $\pm 0.1 \%$, respectively.

Carbon dioxide released from the water to the headspace of the dissolved gas sampling flasks was affected by isotope fractionation. The measured $\delta^{13} \mathrm{C}-\mathrm{CO}_{2}$ values of these gas aliquots $\left(\delta^{13} \mathrm{C}-\mathrm{CO}_{2 \mathrm{STRIP}}\right)$ were used to compute the $\delta^{13} \mathrm{C}$ values of dissolved $\mathrm{CO}_{2}$ according to the $\varepsilon_{1}$ fractionation factor for the gas-water equilibrium (Zhang et al., 1995), as follows:

$\varepsilon_{1}=\delta^{13} \mathrm{C}^{-\mathrm{CO}_{2}}-\delta^{13} \mathrm{C}-\mathrm{CO}_{2 \mathrm{STRIP}}=(0.0049 \times \mathrm{T})-1.31$

The $\delta^{13} \mathrm{C}$ values of $\mathrm{CH}_{4}\left(\delta^{13} \mathrm{C}-\mathrm{CH}_{4}\right)$ from bubbling gases were analyzed by mass spectrometry (Varian MAT 250), according to the procedure reported by Schoell (1980). The analytical uncertainly was $\pm 0.15 \%$. In the dissolved gases, $\mathrm{CH}_{4}$ concentration in the dissolved gases was too low to allow any analysis of $\delta^{13} \mathrm{C}_{-}-\mathrm{CH}_{4}$.

${ }^{3} \mathrm{He} /{ }^{4} \mathrm{He}$ ratios (expressed as $\mathrm{R} / \mathrm{Ra}$, where $\mathrm{R}$ is the ${ }^{3} \mathrm{He} /{ }^{4} \mathrm{He}$ measured ratio and $\mathrm{Ra}$ is the ${ }^{3} \mathrm{He} /{ }^{4} \mathrm{He}$ ratio in the air: $1.3910^{-6}$; Mamyrin and Tolstikhin, 1984) and ${ }^{4} \mathrm{He} /{ }^{20} \mathrm{Ne}$ ratio were analyzed by using a double collector mass spectrometer (VG 5400-TFT) according to method described by Inguaggiato and Rizzo (2004). The analytical error was $\pm 1 \%$. The measured $\mathrm{R} / \mathrm{Ra}$ ratios were corrected for atmospheric contamination ( $\mathrm{Rc} / \mathrm{Ra}$ ) based on the measured ${ }^{4} \mathrm{He} /{ }^{20} \mathrm{Ne}$ ratio (Poreda and Craig, 1989), as follows:

$\mathrm{Rc} / \mathrm{Ra}=\left[\left(\mathrm{R} / \mathrm{Ra}_{\text {measured }}\right)-\mathrm{r}\right] /(1-\mathrm{r})$

where $r$ is the $\left({ }^{4} \mathrm{He} /{ }^{20} \mathrm{Ne}\right)_{\text {Air }} /\left({ }^{4} \mathrm{He} /{ }^{20} \mathrm{Ne}\right)_{\text {measured }}$ and that of $\left({ }^{4} \mathrm{He} /{ }^{20} \mathrm{Ne}\right)_{\text {Air }}$ is 0.318 (Ozima and Podosek, 1983). 


\section{Results}

\subsection{Chemical and isotopic $\left(\delta^{18} \mathrm{O}-\mathrm{H}_{2} \mathrm{O}, \delta \mathrm{D}-\mathrm{H}_{2} \mathrm{O}\right)$ compositions of waters}

Outlet temperatures, $\mathrm{pH}$, Total Dissolved Solids (TDS; in mg/L), and concentrations (in $\mathrm{mg} / \mathrm{L}$ ) of the main constituents in the studied waters are listed in Table 1 . All these chemical-physical parameters varied in a relatively large interval, being comprised between 11.7 and $62.4{ }^{\circ} \mathrm{C}, 4.84$ and 8.65 and 254 and 315,864 mg/L, respectively.

Five different geochemical groups were recognized (Fig. 2a, b and c), as follows:

1) High TDS (from 2395 to $315,810 \mathrm{mg} / \mathrm{L}$ ), $\mathrm{Na}^{+}-\mathrm{Cl}^{-}$waters. These springs, discharging from all the 5 investigated zones, had outlet temperatures and $\mathrm{pH}$ values ranging from 11.7 to $62.4{ }^{\circ} \mathrm{C}$ and from 5.92 to 7.73 , respectively. They had relatively high concentrations of $\mathrm{HCO}_{3}^{-}$(up to $3230 \mathrm{mg} / \mathrm{L}$ ), whereas those of $\mathrm{SO}_{4}^{2-}$ (from 30 to $7860 \mathrm{mg} / \mathrm{L}$ ), $\mathrm{Ca}^{2+}$ (from 91 to $1250 \mathrm{mg} / \mathrm{L}$ ), $\mathrm{Mg}^{2+}$ (from 29 to $4780 \mathrm{mg} / \mathrm{L}$ ) and $\mathrm{K}^{+}$(from 20 to $4376 \mathrm{mg} / \mathrm{L}$ ) showed differences in concentrations up to three orders of magnitude. Relatively high concentrations of B (up to $558 \mathrm{mg} / \mathrm{L}$ ), $\mathrm{F}^{-}$(up to $17 \mathrm{mg} / \mathrm{L}$ ), $\mathrm{Br}^{-}$(up to $83 \mathrm{mg} / \mathrm{L}$ ), $\mathrm{NO}_{3}^{-}$(up to $42 \mathrm{mg} / \mathrm{L}$ ), $\mathrm{NH}_{4}^{+}$(up to $180 \mathrm{mg} / \mathrm{L}$ ), $\mathrm{Li}^{+}$(up to $602 \mathrm{mg} / \mathrm{L}$ ), and $\mathrm{SiO}_{2}$ (up to $169 \mathrm{mg} / \mathrm{L}$ ), were measured (Table 2).

2) $\mathrm{Na}^{+}-\mathrm{HCO}_{3}^{-}\left(\mathrm{Cl}^{-}\right)$waters, which included $\mathrm{P} 1$ and $\mathrm{P} 2$ thermal waters (outlet temperature up to $44.2^{\circ} \mathrm{C}$ ) from the Pairique zone. The TDS values of these neutral waters $(\mathrm{pH} \sim 7$ ) were slightly lower (1753 and $1662 \mathrm{mg} / \mathrm{L}$, respectively) with respect to those shown by the $\mathrm{Na}^{+}-\mathrm{Cl}^{-}$waters. The concentrations of $\mathrm{SO}_{4}^{2-}$ and $\mathrm{SiO}_{2}$ were up to 126 and $111 \mathrm{mg} / \mathrm{L}$, respectively.

3) $\mathrm{Na}^{+}-\mathrm{HCO}_{3}^{-}$thermal waters, which also included those from Coranzulí (C1-C3) and Granada (OR1). Their outlet temperatures were from 24.3 to $32.5^{\circ} \mathrm{C}$, whereas the $\mathrm{pH}$ values ranged from 7.28 to 8.40 . TDS was from 587 to $810 \mathrm{mg} / \mathrm{L}$ and consequently, the concentrations of the chemical species were significantly lower with respect to those of the previous groups.

4) $\mathrm{Ca}^{2+}-\mathrm{SO}_{4}^{2-}$ waters. Only a creek (C4) from Coranzulí showed this composition. Additionally, this sample was characterized by the lowest $\mathrm{pH}$ value (4.84) among the whole water suite. TDS and outlet temperature were of $482 \mathrm{mg} / \mathrm{L}$ and $18.1^{\circ} \mathrm{C}$.

5) $\mathrm{Ca}^{2+}-\mathrm{HCO}_{3}^{-}$waters, including one sample from the Pairique creek (RC4; pH: 8.65) and one thermal spring from Coranzulí (R1) the latter showing $\mathrm{pH}$ and outlet temperature of $22.3^{\circ} \mathrm{C}$ and 7.02 , respectively. These waters were characterized by the lowest TDS values ( 254 and $264 \mathrm{mg} / \mathrm{L}$, respectively) among the studied waters.
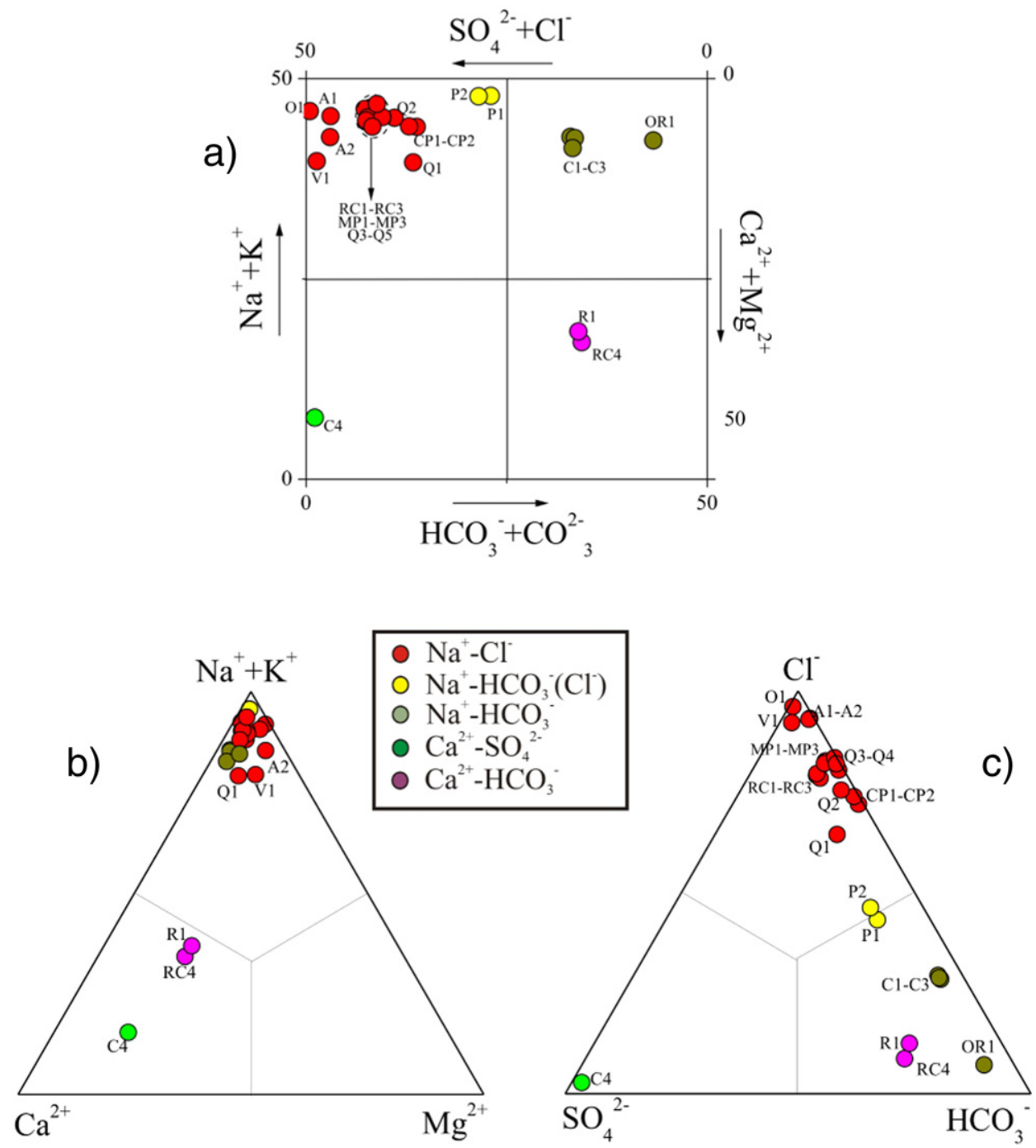

Fig. 2. (a) Langelier-Ludwig Square diagram (Langelier and Ludwig, 1942), (b) $\mathrm{Ca}^{2+}-\left(\mathrm{Na}^{+}+\mathrm{K}^{+}\right)-\mathrm{Mg}^{2+}$ ternary diagram, and (c) $\mathrm{SO}_{4}^{2-}-\mathrm{Cl}^{-}-\mathrm{HCO}_{3}^{-}$ternary diagram for thermal waters from the Puna plateau, Jujuy Province, Argentina. Symbols are: Red circle, $\mathrm{Na}^{+}-\mathrm{Cl}^{-}$water; yellow circle, $\mathrm{Na}^{+}-\mathrm{HCO}_{3}^{-}\left(\mathrm{Cl}^{-}\right)$water; brown circle, $\mathrm{Na}^{+}-\mathrm{HCO}_{3}^{-}$water; green circle, $\mathrm{Ca}^{2+}-\mathrm{SO}_{4}^{2-}$ water; violet circle, $\mathrm{Ca}^{2+}-\mathrm{HCO}_{3}^{-}$water. 
Table 2

Chemical composition (in $\mu \mathrm{g} / \mathrm{L}$ ) of minor elements ( $\mathrm{Mn}, \mathrm{Fe}, \mathrm{Co}, \mathrm{Ni}, \mathrm{Cu}, \mathrm{Zn}, \mathrm{Ba}, \mathrm{As}$, and $\mathrm{Sb}$ ) of thermal waters from the Puna plateau, Jujuy Province, Argentina.

\begin{tabular}{llllllllll}
\hline id & Mn & Fe & Co & Ni & Cu & Zn & Ba & As & Sb \\
\hline O1 & 181 & 238 & 11 & 27 & 48 & 107 & 134 & 459 & 99 \\
V1 & 876 & 9620 & 4.3 & 16 & 35 & 102 & 41 & 6170 & 70 \\
RC1 & 54 & 1070 & 0.9 & & 3.6 & 5.2 & 127 & 3170 & 326 \\
RC2 & 55 & 988 & 1.6 & & 3.5 & 4.9 & 124 & 3040 & 200 \\
RC3 & 53 & 1160 & 1.0 & & 3.4 & 6.0 & 137 & 3310 & 232 \\
RC4 & 3.0 & 1.4 & 0.8 & 6.8 & 5.0 & & 1.7 & 28 & 2.7 \\
CP1 & 2.7 & 65 & 2.1 & & 5.3 & 2.0 & 1443 & 38 & 7.5 \\
CP2 & 2.1 & 148 & 1.4 & & 5.4 & 1.9 & 914 & 34 & 4.0 \\
P1 & 13 & 169 & 0.7 & 1.4 & 5.7 & 4.2 & 41 & 34 & 4.5 \\
P2 & 13 & 161 & 0.3 & 1.9 & 5.8 & 4.5 & 38 & 32 & 4.4 \\
A1 & 16 & 5.6 & 3.5 & & 4.6 & 0.4 & 1210 & 2.9 & 17 \\
A2 & 3.0 & 5.5 & 3.0 & & 4.6 & 0.2 & 2030 & 15 & 3 \\
C1 & 4.2 & 42 & 1.5 & 0.3 & 8.0 & 31 & 17 & 87 & 20 \\
C2 & 4.5 & 44 & 1.2 & 0.2 & 5.8 & 24 & 15 & 90 & 16 \\
C3 & 3.8 & 34 & 1.8 & 0.2 & 7.3 & 21 & 17 & 90 & 17 \\
C4 & 58 & 26 & 2.5 & 1.6 & 5.2 & 12 & 8.0 & 4.8 & 2.8 \\
R1 & 2.5 & 2.6 & 1.2 & 0.5 & 6.4 & 43 & 6.5 & 12 & 3.2 \\
MP1 & 10 & 7.4 & 2.7 & & 5.6 & 2.0 & 52 & 221 & 8.8 \\
MP2 & 7.6 & 3.3 & 3.3 & & 5.9 & 2.1 & 78 & 119 & \\
MP3 & 5.3 & 2.7 & 2.2 & & 6.5 & 1.3 & 92 & 21 & \\
Q1 & 2.2 & 107 & 1.0 & & 5.4 & 2.3 & 15 & 11 & 47 \\
Q2 & 2.4 & 5.2 & 2.9 & 0.1 & 7.9 & 0.8 & 1180 & 13 & 5.1 \\
Q3 & 2.1 & 2.5 & 1.8 & & 5.5 & 1.4 & 1980 & 20 & 18 \\
Q4 & 6.8 & 2.6 & 3.0 & & 6.4 & 1.5 & 2910 & 23 & 3.6 \\
Q5 & 5.5 & 3.0 & 3.1 & & 5.5 & 3.5 & 3300 & 24 & 1.1 \\
OR1 & 3.4 & 3.4 & 1.6 & & 8.1 & 2.0 & 0.4 & 5.2 & 5.5 \\
\hline & & & & & & & & & \\
\end{tabular}

As far as the concentrations of trace elements (Table 2) are concerned, the highest values were measured in the $\mathrm{Na}^{+}-\mathrm{Cl}^{-}$waters and they were dominated by Fe, As and Ba $(9620,6170$ and $3300 \mu \mathrm{g} / \mathrm{L}$, respectively), followed by $\mathrm{Mn}$ (from 2.1 to $876 \mu \mathrm{g} / \mathrm{L}$ ), $\mathrm{Sb}$ (from 1.1 to $326 \mu \mathrm{g} / \mathrm{L}$ ), Zn (from 0.8 to $107 \mu \mathrm{g} / \mathrm{L}$ ), Cu (from 3.4 to $48 \mu \mathrm{g} / \mathrm{L}$ ), Ni (from 0.1 to $27 \mu \mathrm{g} / \mathrm{L}$ ) and Co (from 0.3 to $11 \mu \mathrm{g} / \mathrm{L}$ ).

The $\delta^{18} \mathrm{O}-\mathrm{H}_{2} \mathrm{O}$ and $\delta \mathrm{D}-\mathrm{H}_{2} \mathrm{O}$ values (Table 1 ) of the $\mathrm{Na}^{+}-\mathrm{Cl}^{-}$and $\mathrm{Na}^{+}{ }_{-}$ $\mathrm{HCO}_{3}^{-}\left(\mathrm{Cl}^{-}\right)$waters ranged from -9.8 to -1.3 and from -78 to $-61 \%$ vs. V-SMOW, respectively, whereas those of the remaining water samples ranged from 12.8 to -10.1 and from -94 to $-75 \%$ ovs. VSMOW, respectively. The $\delta^{18} \mathrm{O}-\mathrm{H}_{2} \mathrm{O}$ and $\delta \mathrm{D}-\mathrm{H}_{2} \mathrm{O}$ values of the rainwater samples ranged from -7.8 to -5.7 and from -53 to $-35 \%$ ov. VSMOW.

\subsection{Chemical and isotopic compositions of the dissolved and bubbling gases}

The partial pressure (in mbar) and chemical composition (in $\mathrm{mmol} / \mathrm{mol}$ ) of the dissolved gases are shown in Table 3, where the $\delta^{13} \mathrm{C}_{-} \mathrm{CO}_{2}$ (in \% vs. V-PDB) values are also reported. Dissolved gases associated with the $\mathrm{Na}^{+}-\mathrm{Cl}^{-}$waters were dominated by $\mathrm{CO}_{2}$ (from 766 to $930 \mathrm{mmol} / \mathrm{mol}$ ). Nitrogen was the main dissolved gas compound (from 607 to $695 \mathrm{mmol} / \mathrm{mol}$ ) in the remaining waters, whilst the main atmospheric gases showed concentrations one order of magnitude higher $\left(\mathrm{O}_{2}\right.$ and $\mathrm{Ar}$, up to 260 and $18 \mathrm{mmol} / \mathrm{mol}$, respectively) with respect to those measured in the $\mathrm{CO}_{2}$-dominated samples. Methane and He concentrations ranged from 0.009 to 1.1 and from 0.0075 to $0.016 \mathrm{mmol} / \mathrm{mol}$, respectively, with no significant differences among the different water facies. The $\delta^{13} \mathrm{C}_{-} \mathrm{CO}_{2}$ values ranged from -9.80 to $-21.5 \%$ vs. V-PDB.

The chemical composition of the bubbling gases (in $\mathrm{mmol} / \mathrm{mol}$ ) is shown in Table 4 , where the $\delta^{13} \mathrm{C}-\mathrm{CO}_{2}, \delta^{13} \mathrm{C}_{-} \mathrm{CH}_{4}, \mathrm{Rc} / \mathrm{Ra}$ and ${ }^{4} \mathrm{He} /{ }^{20} \mathrm{Ne}$ values are also reported. Carbon dioxide was largely the most abundant gas species (from 930 to $972 \mathrm{mmol} / \mathrm{mol}$ ), followed by $\mathrm{N}_{2}$ (from 26 to $66 \mathrm{mmol} / \mathrm{mol}$ ), $\mathrm{CH}_{4}$ (from 0.048 to $0.46 \mathrm{mmol} / \mathrm{mol}$ ), $\mathrm{Ar}$ (from 0.55 to $1.4 \mathrm{mmol} / \mathrm{mol}$ ), $\mathrm{O}_{2}$ (from 0.21 to $3.4 \mathrm{mmol} / \mathrm{mol}$ ), $\mathrm{H}_{2}$ (from 0.006 to $0.036 \mathrm{mmol} / \mathrm{mol}$ ), and He (from 0.0007 to $0.0021 \mathrm{mmol} / \mathrm{mol}$ ). Hydrogen sulfide was found at detectable concentrations (from 1.5 to 3.2 $\mathrm{mmol} / \mathrm{mol}$ ) in a few gases from: Vilama (V1), Pairique (RC1, RC2, RC5, and P1), Coranzulì (A2), and Granada (Q2 and Q4) zones. Light hydrocarbons, whose total concentrations were up to $0.0071 \mathrm{mmol} / \mathrm{mol}$, mainly consisted of $\mathrm{C}_{2}-\mathrm{C}_{5}$ alkanes, with significant concentrations of isobutene ( $\mathrm{i}-\mathrm{C}_{4} \mathrm{H}_{8}$ up to $\left.0.00016 \mathrm{mmol} / \mathrm{mol}\right)$ and benzene $\left(\mathrm{C}_{6} \mathrm{H}_{6}\right.$ up to $0.0021 \mathrm{mmol} / \mathrm{mol})$. The $\delta^{13} \mathrm{C}_{-} \mathrm{CO}_{2}$ values ranged from -6.59 to $-13.6 \%$ 。 vs. V-PDB, whereas those of $\delta^{13} \mathrm{C}-\mathrm{CH}_{4}$, measured in selected samples (V1, RC1, RC2, A2, MP1, MP2, and Q4) were from -51.5 to $-29 \%$ vs. V-PDB. The Rc/Ra values were relatively low, ranging from 0.27 to 1.39 .

\section{Discussion}

\subsection{Processes controlling the chemistry of waters}

The $\delta \mathrm{D}-\mathrm{H}_{2} \mathrm{O}$ vs. $\delta^{18} \mathrm{O}-\mathrm{H}_{2} \mathrm{O}$ diagram is a useful tool to investigate potential water sources feeding thermal fluid discharges. In Fig. 3, the Local Meteoric Water Line (LMWL), constructed on the basis of the isotopic composition of the RW1-RW3 samples $\left(\delta \mathrm{D}=8.3 \times \delta^{18} \mathrm{O}\right.$ +11.67 ), and that was basically coincident with that proposed by Hoke et al. (2013) for Central Andes, is reported. Most thermal waters plot in correspondence of LMWL, with the exception of the $\mathrm{Na}^{+}-\mathrm{Cl}^{-}$ waters that are characterized by significant positive isotopic shifts. According to the $\delta^{18} \mathrm{O}-\mathrm{H}_{2} \mathrm{O}$ vertical gradient $(-2.62 \% / \mathrm{km})$ calculated with the isotopic data of the rainwater samples, the meteoric recharge of these springs was likely at an altitude ranging from 4000 to $4500 \mathrm{~m}$ a.s.l. (Fig. 3). Hence, the D- and ${ }^{18} \mathrm{O}$-enrichments of the $\mathrm{Na}^{+}-\mathrm{Cl}^{-}$waters may be interpreted as produced by steam loss due to evaporation occurring at different temperatures (Fig. 3).

The liquid-vapor fractionation factor is indeed dependent on temperature (Horita and Wesolowski, 1994). Thus, those waters with a relatively strong ${ }^{18} \mathrm{O}$ - and ${ }^{2} \mathrm{H}$-shift (O1, V1, RC1-RC3, A1, A2, and MP1-MP3) were possibly affected by steam loss at higher temperatures with respect to those approaching $\mathrm{LMWL}$ (CP1, CP2, and Q1-Q5). It is worth noting that the highest isotope fractionation was recorded in the waters having the highest TDS values (Table 1). This suggests that the isotopic features of the $\mathrm{Na}^{+}-\mathrm{Cl}^{-}$waters may be due to both steam

Table 3

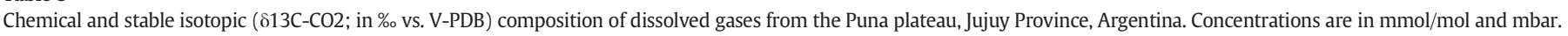

\begin{tabular}{|c|c|c|c|c|c|c|c|c|c|c|c|c|c|}
\hline id & $\mathrm{CO}_{2}$ & $\mathrm{~N}_{2}$ & $\mathrm{CH}_{4}$ & $\mathrm{Ar}$ & $\mathrm{O}_{2}$ & $\mathrm{He}$ & $\delta^{13} \mathrm{C}-\mathrm{CO}_{2}$ & $\mathrm{CO}_{2}$ & $\mathrm{~N}_{2}$ & $\mathrm{CH}_{4}$ & $\mathrm{Ar}$ & $\mathrm{O}_{2}$ & $\mathrm{He}$ \\
\hline OL1 & 930 & 66 & 0.11 & 1.4 & 2.2 & 0.0090 & -9.80 & 118 & 466 & 0.35 & 4.6 & 7.9 & 0.12 \\
\hline $\mathrm{RC} 3$ & 775 & 218 & 0.01 & 5.2 & 1.6 & 0.0081 & -14.1 & 67 & 1052 & 0.024 & 12 & 3.9 & 0.071 \\
\hline $\mathrm{CP} 1$ & 802 & 185 & 0.83 & 4.5 & 8.3 & 0.010 & -12.2 & 32 & 410 & 0.83 & 4.6 & 9 & 0.041 \\
\hline $\mathrm{CP} 2$ & 766 & 221 & 1.1 & 4.8 & 7.6 & 0.016 & -13.6 & 28 & 452 & 1.0 & 4.6 & 7.9 & 0.059 \\
\hline A3 & 890 & 105 & 0.18 & 2.0 & 3.0 & 0.0075 & -11.4 & 45 & 297 & 0.23 & 2.6 & 4.3 & 0.039 \\
\hline $\mathrm{C} 1$ & 248 & 678 & 0.025 & 17 & 56 & 0.014 & -15.4 & 6.6 & 1003 & 0.017 & 12 & 42 & 0.039 \\
\hline $\mathrm{C} 3$ & 254 & 665 & 0.015 & 17 & 65 & 0.014 & -19.6 & 6.6 & 961 & 0.010 & 11 & 48 & 0.036 \\
\hline $\mathrm{R} 1$ & 200 & 682 & 0.011 & 17 & 100 & 0.015 & -16.2 & 5.6 & 1060 & 0.008 & 12 & 79 & 0.041 \\
\hline MP3 & 67 & 655 & 0.009 & 17 & 260 & 0.011 & -20.6 & 2.0 & 1102 & 0.007 & 13 & 223 & 0.033 \\
\hline Q3 & 313 & 607 & 0.15 & 15 & 65 & 0.015 & -17.7 & 8.4 & 904 & 0.10 & 10 & 49 & 0.041 \\
\hline OR1 & 46 & 695 & $\begin{array}{l}0.011 \\
\mathrm{mmol} / \mathrm{mol}\end{array}$ & 18 & 241 & 0.011 & -21.5 & 1.3 & 1060 & $\begin{array}{l}0.008 \\
\text { mbar }\end{array}$ & 12 & 187 & 0.031 \\
\hline
\end{tabular}




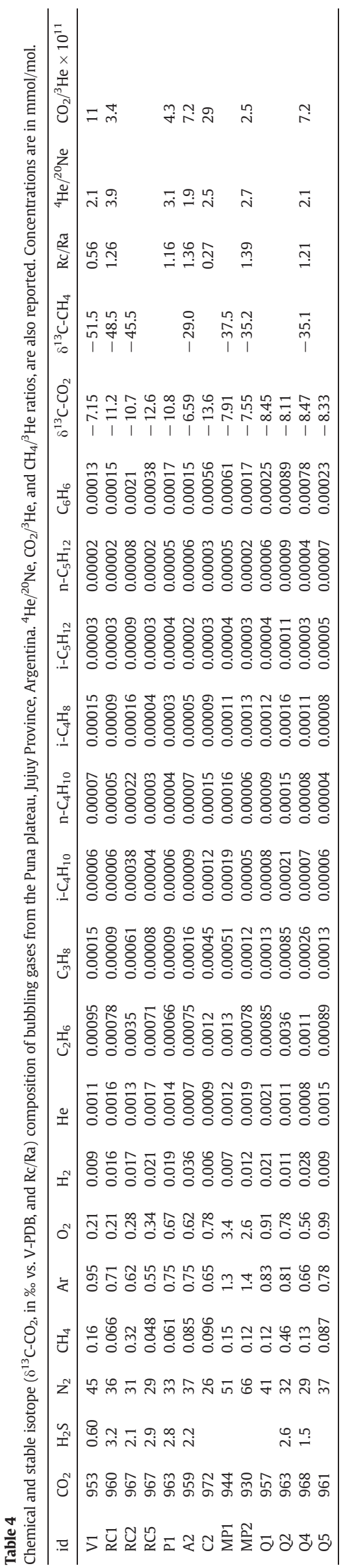

loss and water-rock interaction. Some influence of "andesitic water" (Taran et al., 1989; Giggenbach 1992) would also be consistent with the strongly fractionated $\delta \mathrm{D}-\mathrm{H}_{2} \mathrm{O}$ and $\delta^{18} \mathrm{O}-\mathrm{H}_{2} \mathrm{O}$ data (Fig. 3).

This would imply that the high $\mathrm{Cl}^{-}$concentrations of these waters were related to a magmatic source. However, this process seems to be unlikely since the most recent volcanic activity in the study area dates back to the Neogene (Coira et al., 1993). Moreover, the $\mathrm{Na}^{+} / \mathrm{Cl}^{-}$molar ratios of the $\mathrm{Na}^{+}-\mathrm{Cl}^{-}$waters are stoichiometric (Fig. 4), pointing to a sedimentary source for these elements, e.g. dissolution of halite. Accordingly, water samples with the highest TDS values, i.e. O1, V1, A1 and A2, also have high $\mathrm{Mg}^{2+} / \mathrm{Ca}^{2+}$ and $\mathrm{Cl}^{-} / \mathrm{Br}^{-}$ratios (up to 4.4 and $>1000$, respectively; Fig. 5) and $\mathrm{HCO}_{3}^{-}$and $\mathrm{SO}_{4}^{2-}$ concentrations (up to 2900 and $7860 \mathrm{mg} / \mathrm{L}$, respectively), these geochemical features commonly found in waters interacting with evaporitic deposits (Warren, 2010). This is also supported by the high concentrations of $\mathrm{NH}_{4}^{+}, \mathrm{Li}^{+}$and $\mathrm{B}$ (Table 1 ), which are typically enriched in salt deposits (Helvaci and Alonso, 2000; Garrett, 2004). 01 and V1 discharge in correspondence of salar (Fig. 1), while A1 and A2 are likely related to subsurface saline deposits. Hence, in these sites salt dissolution mostly occurred at the surface and at relatively shallow depth, respectively.

On the contrary, the chemical-physical features of the other $\mathrm{Na}^{+}-\mathrm{Cl}^{-}$ waters were significantly different with respect to those previously considered, since: 1) the outlet temperatures were relatively high, mostly ranging from 29 to $62.4^{\circ} \mathrm{C}$, with the exception of the MP1-MP3 waters (Table 1); 2) the $\mathrm{Mg}^{2+} / \mathrm{Ca}^{2+}$ ratios were relatively low (<0.45; Fig. 5a), as typically recorded in hydrothermal fluids (Giggenbach, 1988) where $\mathrm{Mg}^{2+}$ can easily be removed from solution by interaction with hot rocks (Scott, 1997, and references therein) to form e.g. chlorite; 3) the $\mathrm{Cl}^{-} /$ $\mathrm{Br}^{-}$ratios were $<750$, i.e. in the range of geothermal brines $(\leq 650)$ (Fontes and Matray, 1993; Davis et al., 2001; Risacher et al., 2011) (Fig. 5b). The occurrence of deep hydrothermal reservoir(s), hosting mature $\mathrm{Na}^{+}-\mathrm{Cl}^{-}$waters feeding the thermal discharges of Coranzulì, Granada, and Pairique, is consistent with the (i) ${ }^{18} \mathrm{O}$-enrichment (Fig. 3 ), produced by water-rock interactions at temperatures $>150{ }^{\circ} \mathrm{C}$ (Truesdell and Hulston, 1980), and ii) high $\mathrm{Li}^{+}$and B concentrations (Table 1), since they are preferentially leached from the host rocks rich at high temperature (Brondi et al., 1973; Giggenbach, 1988, 1991;

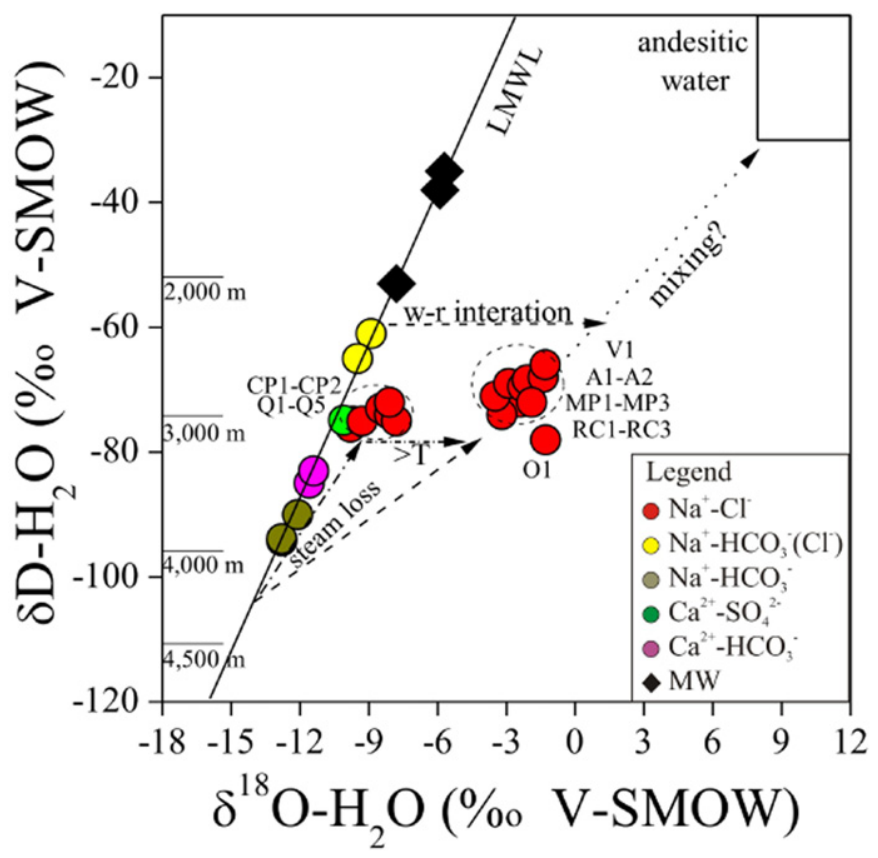

Fig. 3. $\delta \mathrm{D}-\mathrm{H}_{2} \mathrm{O}$ vs. $\delta^{18} \mathrm{O}-\mathrm{H}_{2} \mathrm{O}$ (both in \% vs. V-SMOW) binary diagram. Trends (dash lines) of steam loss at increasing temperatures $(>\mathrm{T}$ ) and the possible mixing trend (dot line) between meteoric and andesitic waters are also reported. Black diamond: meteoric water (MW); other symbols as in Fig. 2. 


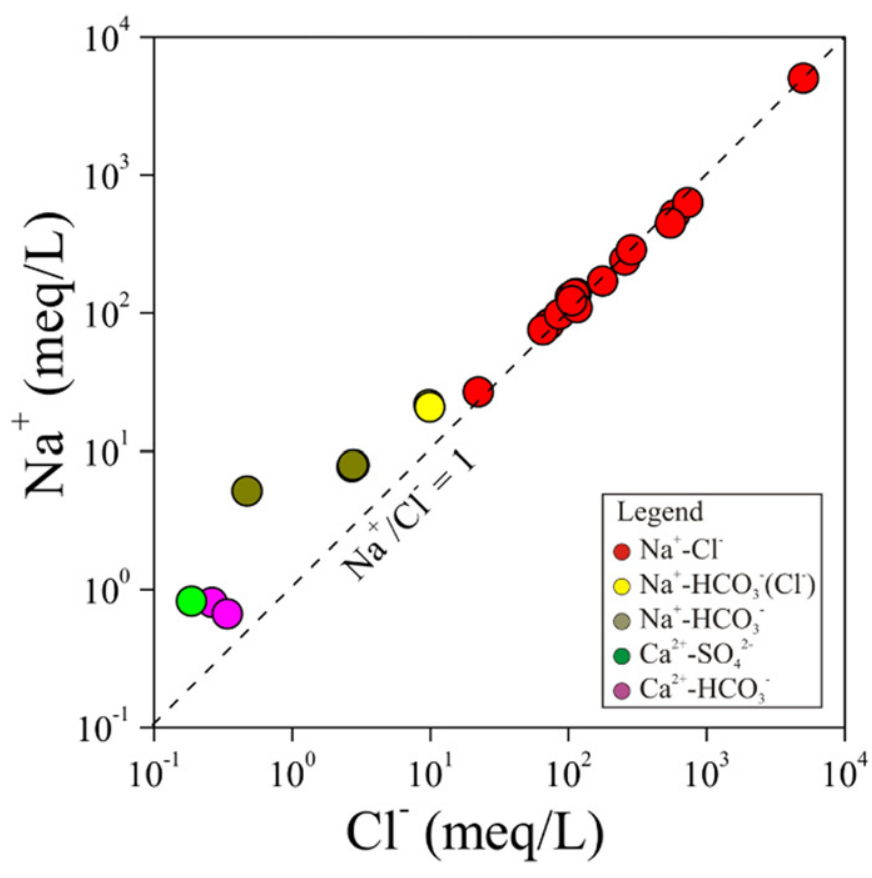

Fig. 4. $\mathrm{Na}^{+}$vs. $\mathrm{Cl}^{-}$(both in meq/L) binary diagram. Symbols as in Fig. 2.

Aggarwal et al., 2000). The relatively high concentrations of As and Sb, as well as those of Fe and $\mathrm{Mn}$ (Table 2), are also in the range of thermal waters discharging from a hydrothermal environment (e.g. Aiuppa et al., 2006; Kaasalainen and Stefánsson, 2012; Wilson et al., 2012; Göb et al., 2013). For example, relatively high As concentrations, comparable to those of the present study, characterize thermal waters from central Italy and were interpreted as due to the structurally controlled uprising of deep-originated fluids (Cinti et al., 2015). However, anomalously high As and $\mathrm{Sb}$ concentrations were also measured in those waters whose chemistry mostly depended on dissolution of salts at the surface (01 and V1). Thus, these elements cannot be unequivocally considered as tracers for geothermal fluids. As expected, those waters interacting with the surficial evaporitic deposits were also enriched in $\mathrm{Co}, \mathrm{Ni}, \mathrm{Cu}$ and $\mathrm{Zn}$ (Table 2), the concentrations of these elements in the other thermal waters were basically similar to those measured in the cold waters, although numerous polymetallic sulfide ore deposits were recognized in the study area. On the contrary, Ba concentrations (>1000 $\mu \mathrm{g} / \mathrm{L})$ in the $\mathrm{Na}^{+}-\mathrm{Cl}^{-}$thermal waters from Cono Panizo, Arituzar and Queñual, were extremely high, i.e. up to two orders of magnitude higher than those commonly found in geothermal waters (up to $60 \mu \mathrm{g} / \mathrm{L}$; Kaasalainen and Stefánsson, 2012). Such a surprising geochemical feature was likely related to the anomalously high Ba contents in most Ordovician and Cenozoic rocks, as testified by the occurrence of barite and sedex deposits (Brodtkorb et al., 1982).

On the whole, the origin of the $\mathrm{Na}^{+}-\mathrm{Cl}^{-}$water discharges is due to (i) dissolution of evaporite deposits, mostly occurring at the surface where salares and salt lakes are present (at Vilama, Olaroz and Arituzar), (ii) contribution of geothermal brines possibly hosted within the preOrdovician crystalline basement, or (iii) a combination of these two processes. The relatively high $\mathrm{HCO}_{3}^{-}$and $\mathrm{SO}_{4}^{2-}$ concentrations measured in most waters were possibly depending on the interaction with carbonate and gypsum layers that were recognized in the Mesozoic and Miocene sedimentary formations.

The origin of the $\mathrm{Na}^{+}-\mathrm{HCO}_{3}^{-}$waters was likely due to water-rock interaction processes involving $\mathrm{Na}$-silicates from the volcanic products cropping out in the study areas (Caffe et al., 2012) and/or the Cretaceous conglomerates of Salta Subgroup that includes carbonate-rich the Pirgua Subgroup and Yacoraite formations (Fig. 1). Accordingly, their $\mathrm{Na}^{+} / \mathrm{HCO}_{3}^{-}$molar ratios are approaching the stoichiometric straight line (Fig. 6), and both the TDS values and the $\mathrm{CO}_{2}$ concentrations in the associated gas phase were relatively low, indicating a relatively shallow hydrological circuit, with no significant contribution from the $\mathrm{Na}^{+}-$ $\mathrm{Cl}^{-}$deep reservoir. Thus, it can be suggested that the deep and shallow aquifers are locally connected by faults, allowing a mixing between the $\mathrm{Na}^{+}-\mathrm{Cl}^{-}$and $\mathrm{Na}^{+}-\mathrm{HCO}_{3}^{-}$end-members, to produce $\mathrm{Na}^{+}-\mathrm{HCO}_{3}^{-}\left(\mathrm{Cl}^{-}\right)$

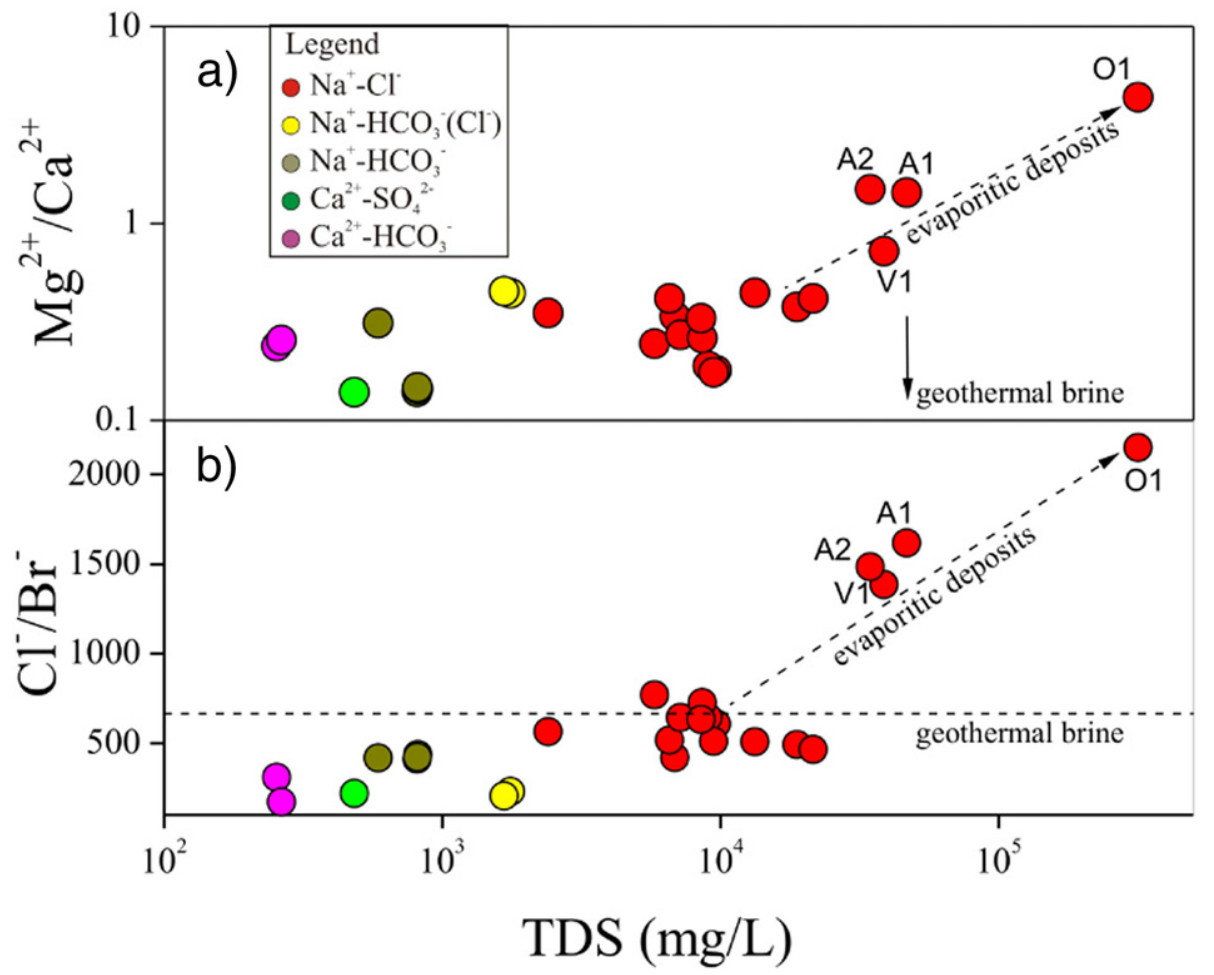

Fig. 5. (a) $\mathrm{Mg}^{2+} / \mathrm{Ca}^{2+}$ and (b) $\mathrm{Cl}^{-} / \mathrm{Br}^{-}$vs. TDS (in mg/L) binary diagrams. Symbols as in Fig. 2 . 


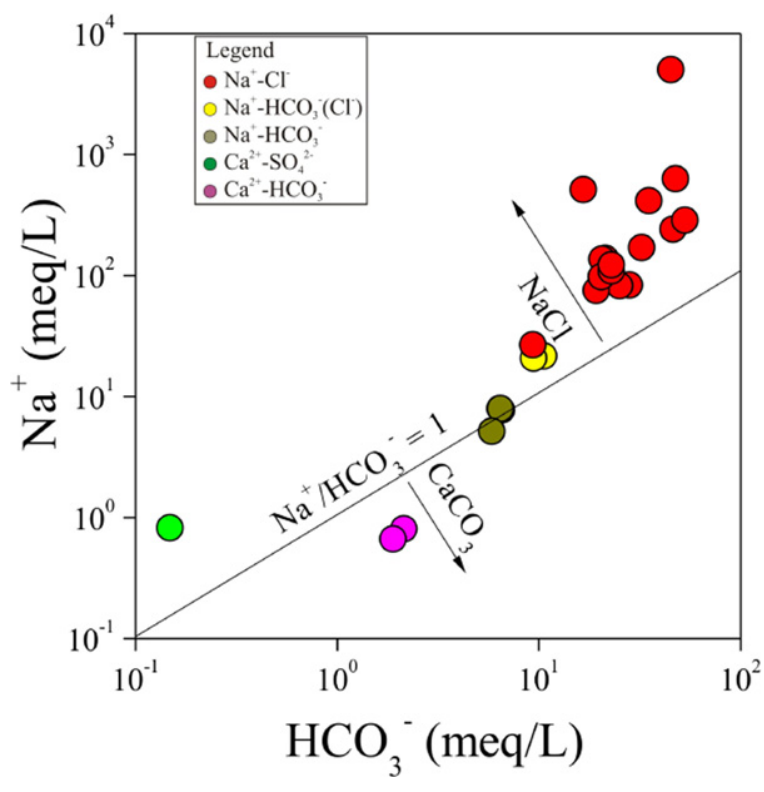

Fig. 6. $\mathrm{Na}^{+}$vs. $\mathrm{HCO}_{3}^{-}$(both in meq/L) binary diagram. Symbols as in Fig. 2 .

waters. The $\mathrm{Ca}^{2+}-\mathrm{SO}_{4}^{2-}$ composition and low $\mathrm{pH}$ and TDS values (4.84 and $587 \mathrm{mg} / \mathrm{L}$, respectively) of the creek named C4 (Table 1) were possibly produced by both $\mathrm{H}_{2} \mathrm{~S}$ dissolution in meteoric water, although no gas emergence was recognized along this creek, and leaching of gypsum-rich evaporitic deposits in the upper reaches of this surface water. On the other hand, the $\mathrm{Ca}^{2+}-\mathrm{HCO}_{3}^{-}$creeks basically consisted of meteoric water with no inputs of waters or gases from depth.

\subsection{Origin of gases}

Water chemistry suggested that the thermal springs were affected at different degrees by hydrothermal fluids uprising from a deep Paleozoic reservoir. Approaching the surface, these fluids were diluted by shallow $\mathrm{Na}^{+}-\mathrm{HCO}_{3}^{-}$-type aquifer(s). Secondary interactions with evaporitic deposits added salinity (high TDS) and related solutes to the springs emerging in correspondence of salares. The carbon isotopic signature of $\mathrm{CO}_{2}$ in the bubbling gases associated with most $\mathrm{Na}^{+}-\mathrm{Cl}^{-}$waters (Table 4) was in the range of gases from mantle degassing (from $-9 \%$ to $-2 \%$ vs. V-PDB; Barnes et al., 1978; Javoy et al., 1982; Rollinson, 1993; Ohmoto and Goldhaber, 1997; Hoefs, 2009). However, their high $\mathrm{CO}_{2} /{ }^{3} \mathrm{He}$ ratios (up to $2.9 \times 10^{12}$; Table 4 ), up to three orders of magnitude higher than the mantle value $\left(\sim 1.2 \times 10^{9}\right.$; Marty and Jambon, 1987), allow to exclude a significant contribution of mantle $\mathrm{CO}_{2}$, notwithstanding the occurrence of up to $16 \%$ of mantle $\mathrm{He}$, as indicated by the Rc/Ra values (Poreda and Craig, 1989; Hilton et al., 2002). Moreover, the bubbling gases from Rosario de Coyaguayma at Pairique, as well as those associated with the P1 and C2 waters (Table 4), showed more negative isotopic values (from $-13.6 \%$ to $-10.7 \%$ 。 v. V-PDB), confirming that most hydrothermal $\mathrm{CO}_{2}$ originated from a crustal source (Hoefs, 2009). However, the increasing trend of the $\delta^{13} \mathrm{C}^{13} \mathrm{CO}_{2}$ values with increasing partial pressure of $\mathrm{CO}_{2}$ in the dissolved gases (Fig. 7) indicates the addition of isotopically heavy mantle-like $\mathrm{CO}_{2}$ to biogenic shallow carbon (O'Leary, 1988; Hoefs, 2009). This evidence can be concealed with the high $\mathrm{CO}_{2} /{ }^{3} \mathrm{He}$ ratios measured in these gases admitting that these gases were at least partially fed by mantle source characterized by relatively high Carbon contents, possibly due to organic rich sediment contamination related to the subduction process.

The $\mathrm{N}_{2} / \mathrm{Ar}$ ratios, ranging between 39 and 53, were consistent with those of air-saturated water (ASW: 38-42 at temperature between 20 and $70{ }^{\circ} \mathrm{C}$ ), suggesting that, not being available any $\delta^{15} \mathrm{~N}-\mathrm{N}_{2}$ value, air dissolved in the meteoric recharging system of the hydrothermal

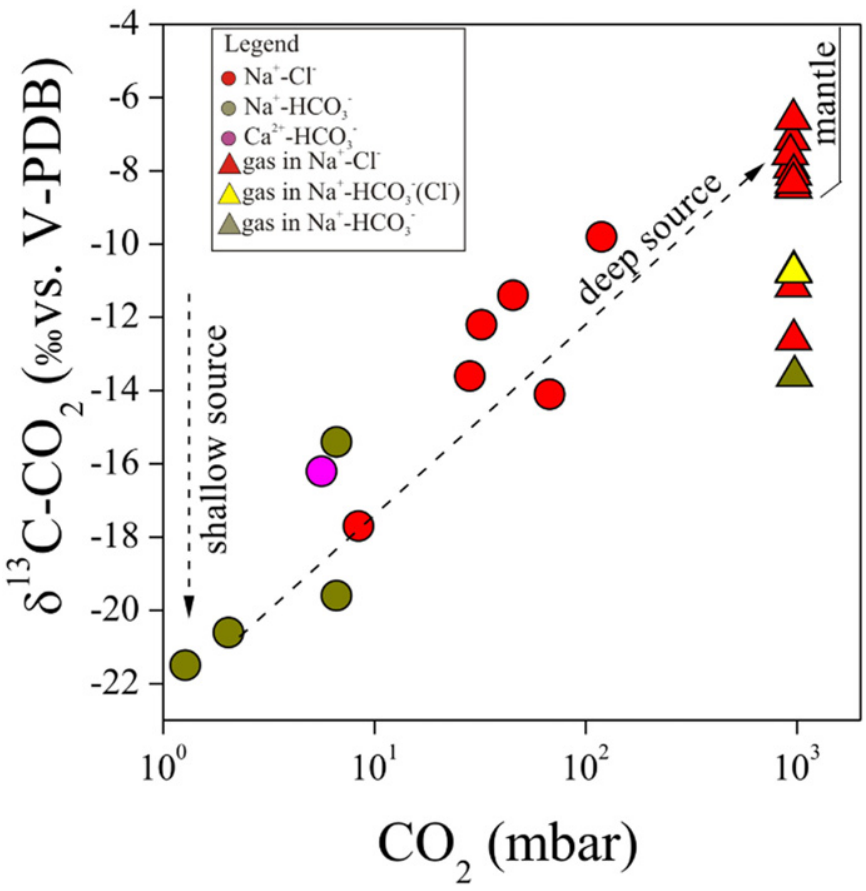

Fig. 7. $\delta^{13} \mathrm{C}^{-\mathrm{CO}_{2}}$ (\% vs. V-PDB) vs. $\mathrm{CO}_{2}$ (mbar) binary diagram. Symbols of dissolved gases as in Fig. 2. Symbols of bubbling gases are: Red triangle: gas associated with $\mathrm{Na}^{+}-\mathrm{Cl}^{-}$ water; yellow triangle, gas associated with $\mathrm{Na}^{+}-\mathrm{HCO}_{3}^{-}\left(\mathrm{Cl}^{-}\right)$water; brown triangle, gas associated with $\mathrm{Na}^{+}-\mathrm{HCO}_{3}^{-}$water.

aquifer was the main source for $\mathrm{N}_{2}$ and Ar. The occurrence of $\mathrm{O}_{2}$ (Table 4) indicated that the infiltrating meteoric waters, which interacted with the uprising hydrothermal fluids, were supplying the atmospheric gases to the thermal springs. This would also explain the strongly variable concentrations of $\mathrm{H}_{2} \mathrm{~S}$ (Table 4), which was likely produced within the hydrothermal reservoir and successively oxidized in presence of free $\mathrm{O}_{2}$ when fluids approached the surface.

The $\delta^{13} \mathrm{C}_{-} \mathrm{CH}_{4}$ values, as well as the $\mathrm{CH}_{4} / \mathrm{C}_{2}+$ ratios ( $<103$ ), were consistent with those classically interpreted as related to thermogenic processes involving pre-existing organic matter (e.g. Schoell, 1980, 1988; Whiticar et al., 1986; Whiticar, 1999). Hence, light hydrocarbons possibly originated at reducing conditions typical of a hydrothermal reservoir, where $\mathrm{H}_{2}$ was also produced. The V1, RC1 and RC2 gases, showing more negative $\delta^{13} \mathrm{C}_{-} \mathrm{CH}_{4}$ values, were possibly affected by some contribution of biogenic $\mathrm{CH}_{4}$.

\subsection{Geothermometry}

Equilibrium temperatures of hydrothermal reservoirs based on the concentrations of $\mathrm{SiO}_{2}$ in the liquid phase depend on the dissolution of different silica mineral. The dependences on temperature of the solubility of chalcedony (Arnorsson, 1983) and quartz (Fournier, 1977) can be expressed, as follows:

$\mathrm{T}\left({ }^{\circ} \mathrm{C}\right)=1112 /\left(4.91-\log \mathrm{SiO}_{2}\right)-273.15$

and

$\mathrm{T}\left({ }^{\circ} \mathrm{C}\right)=1309 /\left(5.19-\log \mathrm{SiO}_{2}\right)-273.15$

where $\mathrm{SiO}_{2}$ is in $\mathrm{mg} / \mathrm{L}$. At temperatures $<180{ }^{\circ} \mathrm{C}$, such as those estimated by both Eqs. (3) and (4) for the studied waters, excluding the low-TDS creeks (RC4 and C4) and the thermal waters whose chemistry was largely determined by interaction with salar deposits (01, V1, A1 and 
A2), chalcedony is the dominant silica mineral. Thus, Eq. (3) likely provides the most reliable results. In particular, RC1-RC3 apparently equilibrated at $137-142{ }^{\circ} \mathrm{C}$, a temperature range similar to that calculated for the Q2-Q5 waters $\left(134-142^{\circ} \mathrm{C}\right)$ and slightly higher than those obtained for the $\mathrm{CP} 1-\mathrm{CP} 2\left(128-131^{\circ} \mathrm{C}\right)$ and $\mathrm{P} 1-\mathrm{P} 2\left(114-115^{\circ} \mathrm{C}\right)$ waters. Estimated equilibrium temperatures for the $\mathrm{C} 1-\mathrm{C} 3$ and MP1-MP3 and R1 waters were significantly lower (93-100, 79-84 and $72{ }^{\circ} \mathrm{C}$, respectively). Although no direct measurement of temperature at depth is available to verify the reliability of these theoretical results, it has to be underlined that the silica geothermometers strongly depend on dilution and steam loss, which possibly affected the hydrothermal fluids producing underestimated and overestimated equilibrium temperatures, respectively. Geothermometry techniques based on the chemical equilibria in the Na-K-Mg system were commonly adopted for aqueous solutions interacting with the typical authigenic mineral assemblage (including Na- and K-feldspars, K-micas, chlorite and silica) of medium-to-high temperature $\left(150-300{ }^{\circ} \mathrm{C}\right)$ hydrothermal systems. Using this approach, equilibrium temperatures are less affected by secondary processes, being computed on the basis of their dependences on the $\mathrm{Na}^{+} / \mathrm{K}^{+}$and $\mathrm{K}^{+} / \mathrm{Mg}^{2+}$ ratios (Giggenbach, 1988), as follows:

$\mathrm{T}\left({ }^{\circ} \mathrm{C}\right)=1390 /\left(1.75-\log \left[\mathrm{Na}^{+} / \mathrm{K}^{+}\right]\right)-273.15$

and

$\mathrm{T}\left({ }^{\circ} \mathrm{C}\right)=4410 /\left(14.0-\log \left[\mathrm{K}^{+}\left({ }^{2}\right) / \mathrm{Mg}^{2+}\right]\right)-273.15$

In the $\mathrm{Na}^{+} / 400-\mathrm{K}^{+} / 10-\sqrt{\mathrm{Mg}^{2+}}$ ternary diagram (Fig. 8), the fields of "full equilibrium", "partial equilibrium" and "immature waters" were obtained by combining the fast $\mathrm{K}-\mathrm{Mg}$ and the slow $\mathrm{Na}-\mathrm{K}$ geothermometers (Giggenbach 1988). As expected, the $\mathrm{Na}-\mathrm{K}$ geothermometer produced temperatures were significantly higher than those estimated with the silica geothermometer. The RC1-RC3 waters seem to have attained partial equilibrium at $198-204^{\circ} \mathrm{C}$, i.e. a range of temperature significantly higher than those of both Q2-Q4 and MP1MP3 (155-174 and $163-167{ }^{\circ} \mathrm{C}$, respectively). The P1 and P2 waters

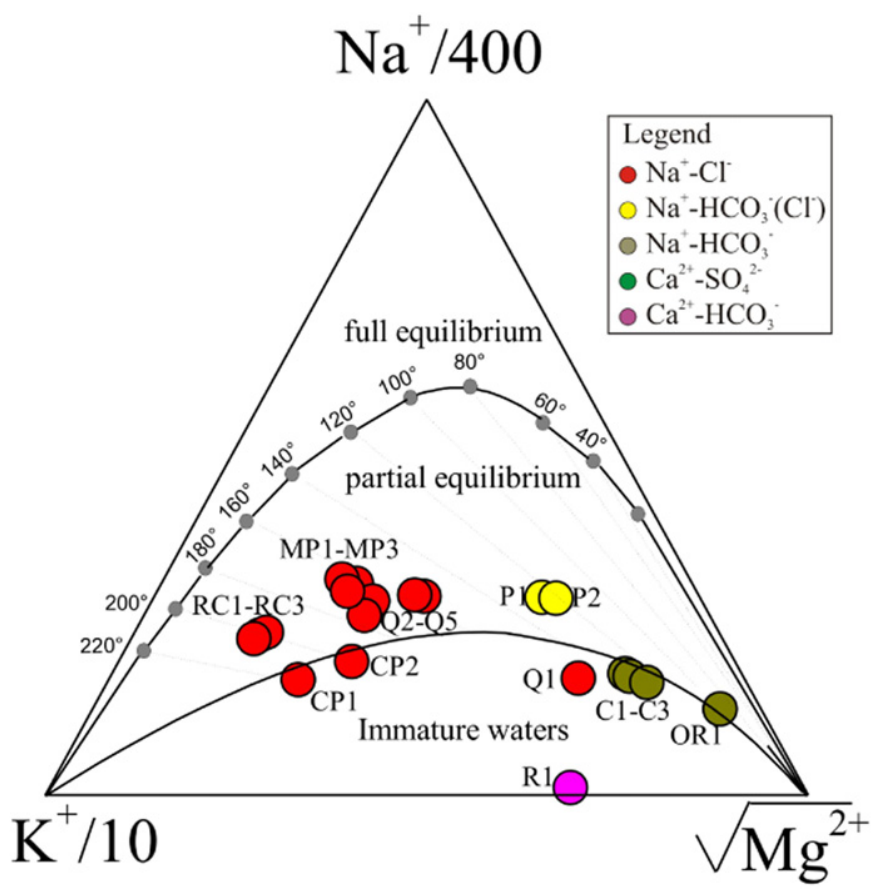

Fig. 8. $\mathrm{Mg}^{2+}-\mathrm{Na}^{+}-\mathrm{K}^{+}$ternary diagram (Giggenbach, 1988). The axes $(\mathrm{Na} / 400-\mathrm{K} / 10-\sqrt{\mathrm{Mg}})$ were modified to enlarge the low temperature area of the diagram. Partial and full equilibrium curves from 40 to $220^{\circ} \mathrm{C}$ are reported. Symbols as in Fig. 2. approached equilibrium at $121-125^{\circ} \mathrm{C}$, whereas the $\mathrm{CP} 1, \mathrm{CP} 2, \mathrm{C} 1-\mathrm{C} 3$, Q1, OR1 and R1 waters were too immature to provide reliable temperature estimations. To evaluate the effect of $\mathrm{Ca}^{2+}$ on these calculations, chemical equilibria in the $\mathrm{Na}-\mathrm{K}-\mathrm{Mg}$-Ca system were also considered. However, in the $\left(10 \mathrm{~K}^{+} /\left[10 \mathrm{~K}^{+}+\mathrm{Na}^{+}\right]\right.$vs. $10 \mathrm{Mg}^{2+} /\left[10 \mathrm{Mg}^{2+}\right.$ $+\mathrm{Ca}^{2+}$ ]) diagram (Fig. 9) all samples plot far from the equilibrium curve proposed by Giggenbach (1988), suggesting that the mineral assemblage used to construct this diagram was not appropriate for these waters. Assuming that the mineral assemblage controlling the $\mathrm{Ca}^{2+}$ / $\mathrm{Mg}^{2+}$ ratios included calcite, dolomite, anhydrite, fluorite and chalcedony, likely occurring in the sedimentary formations overlying the Paleozoic basement, we obtain the following equation (Chiodini et al., 1995):

$$
\begin{aligned}
\log \left(\mathrm{Ca}^{2+} / \mathrm{Mg}^{2+}\right)= & 3.117-979.8 /(\mathrm{T}+273.15)+0.03904 \\
& \times \log \left(\mathrm{PCO}_{2}\right)+0.07003 \times \log \left(\Sigma_{\mathrm{M}}\right)
\end{aligned}
$$

where $\mathrm{T}$ is the temperature (in ${ }^{\circ} \mathrm{C}$ ), $P \mathrm{PO}_{2}$ is the partial pressure of $\mathrm{CO}_{2}$ (in bar) and $\Sigma_{\mathrm{M}}$ is the water salinity (in mol/L). At $P \mathrm{PO}_{2}$ ranging from 1 to 100 bar and $\Sigma_{\mathrm{M}}$ values consistent with those of the waters (from 0.02 to $0.2 \mathrm{~mol} / \mathrm{L})$, the RC1-RC3 $\left(\sim 200{ }^{\circ} \mathrm{C}\right), \mathrm{Q} 1-\mathrm{Q} 5\left(155-175{ }^{\circ} \mathrm{C}\right)$, MP1-MP3 $\left(155-165^{\circ} \mathrm{C}\right)$, and P1-P2 $\left(\sim 125^{\circ} \mathrm{C}\right)$ waters approached the new equilibrium curves (Fig. 9 ) at the same temperatures indicated by the $\mathrm{Na}-\mathrm{K}-\mathrm{Mg}$ geothermometer.

It is worth noting that these computed temperatures should be considered with caution, due to the complex lithologies of the study areas and the possible occurrence of secondary processes affecting the chemistry of the thermal waters during their uprising to the surface.

\subsection{Gas geothermometry}

The chemical composition of the bubbling gases associated with the water discharges can be used to provide further information on temperature, pressure and redox conditions dominating at the fluid source region. The gas discharges, consisting of low-to medium temperature bubbling pools, were affected by condensation of water vapor and dissolution of soluble species, such as CO due to formate production. Therefore, the classical approach based on chemical equilibria in the

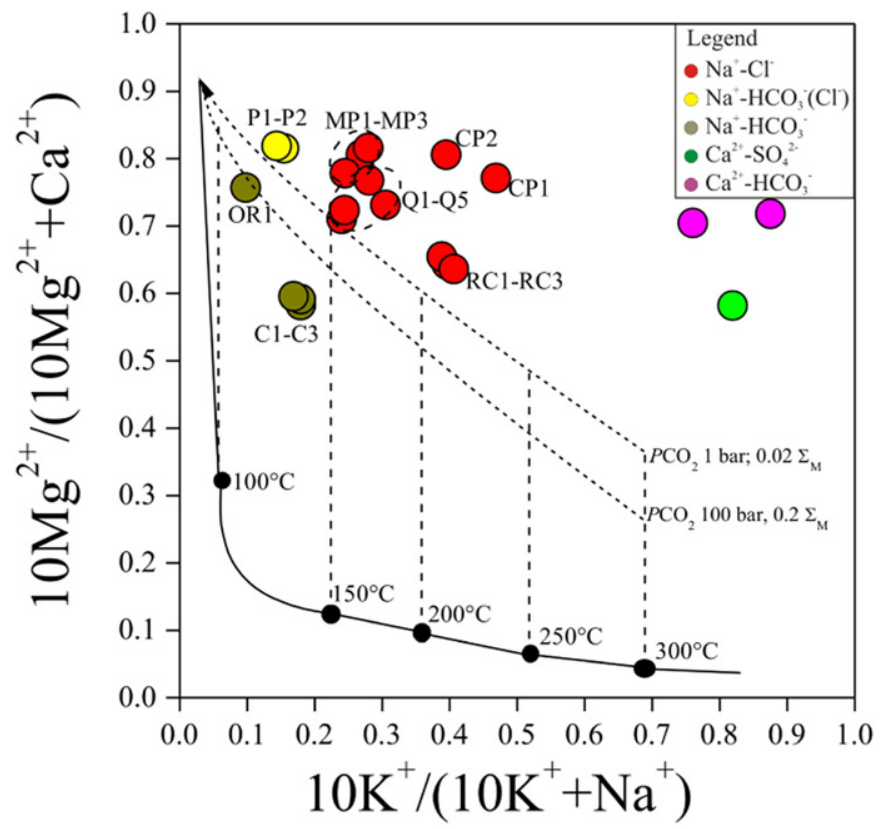

Fig. 9. $\left(10 \mathrm{~K}^{+} /\left[10 \mathrm{~K}^{+}+\mathrm{Na}^{+}\right]\right.$vs. $\left.10 \mathrm{Mg}^{2+} /\left[10 \mathrm{Mg}^{2+}+\mathrm{Ca}^{2+}\right]\right)$ binary diagram. Equilibrium curves from 100 to $300{ }^{\circ} \mathrm{C}$ in presence of different mineral assemblages (Giggenbach, 1988; Chiodini et al., 1995) are reported. Symbols as in Fig. 2. 
$\mathrm{H}_{2} \mathrm{O}-\mathrm{CO}_{2}-\mathrm{CH}_{4}-\mathrm{CO}-\mathrm{H}_{2}$ system cannot fully be applied, since the concentrations of water vapor and $\mathrm{CO}$ depend on secondary processes mostly occurring at the surface. Gas geothermometry was thus carried out in the $\mathrm{CO}_{2}-\mathrm{CH}_{4}-\mathrm{H}_{2}$ system, which was assumed to be mainly regulated by the Sabatier reaction, as follows:

$\mathrm{CH}_{4}+2 \mathrm{H}_{2} \mathrm{O} \Leftrightarrow \mathrm{CO}_{2}+4 \mathrm{H}_{2}$

Assuming that $\log f \mathrm{H}_{2} \mathrm{O}=4.9-1820 / \mathrm{T}$ and $\mathrm{R}_{\mathrm{H}}=\log \left(\mathrm{H}_{2} / \mathrm{H}_{2} \mathrm{O}\right)$ (Giggenbach, 1987), the dependence on temperature and $\mathrm{R}_{\mathrm{H}}$ of the log-ratios between the mole fractions of $\mathrm{CO}_{2}$ and $\mathrm{CH}_{4}\left(\mathrm{X}_{\mathrm{CO} 2}\right.$ and $\mathrm{X}_{\mathrm{CH} 4}$, respectively) in equilibrated vapor and liquid phases can be expressed, as follows:

$$
\log \left(\mathrm{X}_{\mathrm{CH}_{4}} / \mathrm{X}_{\mathrm{CO}_{2}}\right)_{\mathrm{V}}=4 \mathrm{R}_{\mathrm{H}}+5181 / \mathrm{T}(\mathrm{K})
$$

and

$$
\log \left(\mathrm{X}_{\mathrm{CH}_{4}} / \mathrm{X}_{\mathrm{CO}_{2}}\right)_{\mathrm{L}}=4 \mathrm{R}_{\mathrm{H}}+5181 / \mathrm{T}+\log \left(\mathrm{B}_{\mathrm{CO}_{2}}\right)-\log \left(\mathrm{B}_{\mathrm{CH}_{4}}\right)
$$

where $\mathrm{B}_{\mathrm{CO}_{2}}$ and $\mathrm{B}_{\mathrm{CH}_{4}}$ are the vapor/liquid distribution coefficients of $\mathrm{CO}_{2}$ and $\mathrm{CH}_{4}$, respectively.

Assuming that $\mathrm{Ar}$ is fixed by the equilibrium between the atmosphere and air saturated water (ASW), the dependence of $\mathrm{H}_{2}$ on $\mathrm{R}_{\mathrm{H}}$ in the two phases is given by (Giggenbach, 1991):

$$
\log \left(\mathrm{X}_{\mathrm{H}_{2}} / \mathrm{X}_{\mathrm{Ar}^{*}}\right)_{\mathrm{V}}=\mathrm{R}_{\mathrm{H}}+6.52-\log \left(\mathrm{B}_{\mathrm{Ar}}\right)
$$

and

$$
\log \left(\mathrm{X}_{\mathrm{H}_{2}} / \mathrm{X}_{\mathrm{Ar}^{*}}\right)_{\mathrm{L}}=\mathrm{R}_{\mathrm{H}}+6.52-\log \left(\mathrm{B}_{\mathrm{H}_{2}}\right)
$$

where $\mathrm{B}_{\mathrm{Ar}}$ and $\mathrm{B}_{\mathrm{H} 2}$ are the vapor/liquid distribution coefficients of $\mathrm{Ar}$ and $\mathrm{H}_{2}$, respectively, whilst the Ar* values, considering that hydrothermal fluids are $\mathrm{O}_{2}$-free, were calculated, as follows:

$\mathrm{Ar}^{*}=\mathrm{Ar}-\left(\mathrm{O}_{2} / 22\right)$

where the $\mathrm{O}_{2} / 22$ ratio is the Ar concentration due to atmospheric contamination, although this value represents a minimum estimation of $\mathrm{Ar}$ addition at the surface since $\mathrm{O}_{2}$ is rapidly consumed by redox reactions even at shallow depth. According to Eqs. (9)-(12), the $\log \left(\mathrm{X}_{\mathrm{H}_{2}} /\right.$ $\left.\mathrm{X}_{\mathrm{Ar}}{ }^{*}\right)$ vs. $\log \left(\mathrm{X}_{\mathrm{CH}_{4}} / \mathrm{X}_{\mathrm{CO}_{2}}\right)$ diagram (Fig. 10) was constructed assuming that the $R_{H}$ values were controlled by the DP redox buffer system (D'Amore and Panichi, 1980). At these conditions, the bubbling gases plot on the left of the liquid equilibrium curve, in correspondence of $\mathrm{H}_{2}$ equilibrium temperatures ranging from 105 to $155^{\circ} \mathrm{C}$, with no clear distinction among gases from the different study zones.

In most cases, these temperatures were significantly lower than those computed in the Na-K-Mg-Ca system (Figs. 8 and 9), possibly due to (i) re-equilibration of the fast $\mathrm{H}_{2}$ geothermometer during the hydrothermal fluid uprising and/or (ii) $\mathrm{H}_{2}$ consumption within the $\mathrm{O}_{2}$-rich pools from where the bubbling gases were discharged. The apparent disequilibrium of the $\mathrm{CH}_{4}-\mathrm{CO}_{2}$ pair was possibly caused by the slow kinetics that characterizes Reaction (8) especially at relatively low temperatures (Taran and Giggenbach, 2003), such as those of the study systems $\left(\leq 200{ }^{\circ} \mathrm{C}\right)$. Hence, the $\mathrm{CH}_{4}$ concentrations, up to one order of magnitude lower than those expected if the $\mathrm{CO}_{2}-\mathrm{CH}_{4}$ equilibrium was attained at the chemical-physical condictions indicated by the $\mathrm{H}_{2}$ geothermometer (Fig. 10), were only controlled by thermogenic and, partially, biogenic degradation of organic matter, as also confirmed by the $\delta^{13} \mathrm{C}^{1} \mathrm{CH}_{4}$ and $\mathrm{CH}_{4} / \mathrm{C}_{2}$ values.

\section{Conclusions}

The chemical and isotopic compositions of waters and gases from the thermal springs of northern Puna plateau in the Jujuy Province

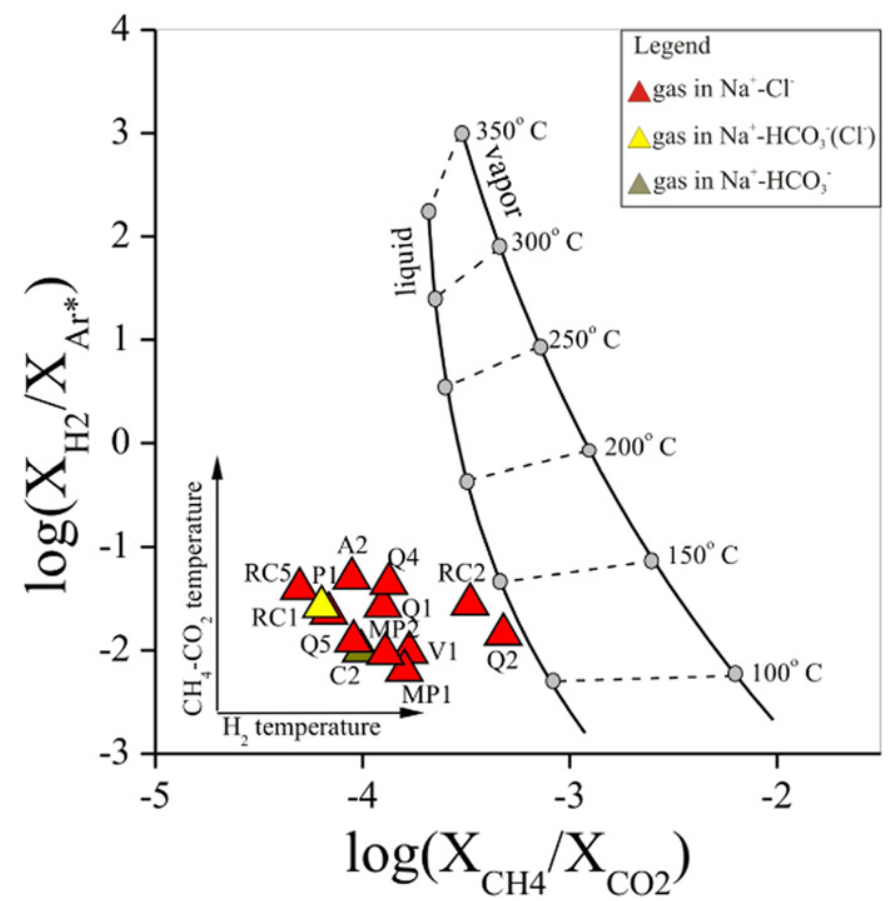

Fig. 10. $\log \left(\mathrm{X}_{\mathrm{H}_{2}} / \mathrm{X}_{\mathrm{Ar}^{\circ}}\right)$ vs. $\log \left(\mathrm{X}_{\mathrm{CH}_{4}} / \mathrm{X}_{\mathrm{CO}_{2}}\right)$ binary diagram. Equilibrium curve in liquid and vapor phases from 100 to $350{ }^{\circ} \mathrm{C}$ at redox conditions controlled by the DP buffer system (D'Amore and Panichi, 1980) are reported. Symbols as in Fig. 7.

were likely related to the occurrence of a deep-seated hydrothermal system fed by meteoric water infiltrating at 4000-4500 $\mathrm{m}$ a.s.l. through the outcropping Ordovician rocks (Auge et al., 2006). The thermal reservoir is hosted in the pre-Ordovician crystalline basement that is likely characterized by secondary permeability. Deep regional tectonic lineaments, also responsible for a limited fluid (He) contribution from mantle degassing, act as preferential pathways for the uprising of the $\mathrm{Na}^{+}-\mathrm{Cl}^{-}$geothermal fluids, especially in the Pairique and Granada zones. Carbonates and gypsum hosted within the Miocene sedimentary formations controlled the $\mathrm{Ca}^{2+}-\mathrm{Mg}^{2+}$ ratios and added $\mathrm{HCO}_{3}^{-}$and $\mathrm{SO}_{4}^{2-}$ to the discharging waters, although the latter might partly be related to the dissolution of $\mathrm{CO}_{2}$ and $\mathrm{H}_{2} \mathrm{~S}$ from the gas phase. $\mathrm{Na}^{+}-\mathrm{HCO}_{3}^{-}$waters, mostly occurring in the Coranzulì zone, developed at relatively shallow depth within the volcanic sequences. These rocks are characterized by a relatively low permeability, and they can likely be acting as an efficient cap for the underlying geothermal aquifer. Cretaceous sediments of the Pirgua Subgroup may host relatively small $\mathrm{Na}^{+}-\mathrm{HCO}_{3}^{-}$reservoirs. The hot and deep aquifer locally mixed with the shallower one, giving rise to waters with an intermediate chemical character. In the southern and western periphery of the study area, i.e. at Olaroz and Vilama zones, and at the Arituzar site in the Coranzulì zone, the chemistry of the thermal springs was strongly affected by dissolution of salt deposits at the surface. Hence, the only clear clues of a deep fluid input were shown by the $\delta^{13} \mathrm{C}-\mathrm{CO}_{2}$ and Rc/ Ra values in the associated gases.

According to this conceptual model, water geothermometry in the $\mathrm{Na}-\mathrm{K}-\mathrm{Mg}-\mathrm{Ca}$ system suggested that the maximum temperature of the deep $\mathrm{Na}^{+}-\mathrm{Cl}^{-}$reservoir is up to $\sim 200{ }^{\circ} \mathrm{C}$, similar to those estimated for the Paleozoic reservoir likely feeding the high altitude (>4000 $\mathrm{m}$ a.s.l.) $\mathrm{Na}^{+}-\mathrm{Cl}^{-}$thermal waters of Tuzgle-Tocomar, which are located $100 \mathrm{~km} \mathrm{~S}$ of the study area (Giordano et al., 2013). Despite the great depth (>5000 $\mathrm{m}$ b.g.l.) of this potentially interesting geothermal resource, the occurrence of Li- and Ba-rich mineralization of valuable economic interest associated with the hydrothermal fluids may generate a strong pulse for the development of this remote region. 


\section{Acknowledgements}

This work was supported by the Laboratory of Fluid and Rock Geochemistry of the Department of Earth Sciences and CNR-IGG of Florence (FT), and grants PIO UNJu-CONICET 14020140100010CO, and FONARSEC FITR Industria 2013 Nº $^{\circ}$ (2013-9). E. Calvi (CNR-IGG Pisa) and M. Paolieri (Dept. Earth Sciences of Florence) are gratefully thanked for their help during the analysis of $\delta^{13} \mathrm{C}^{-\mathrm{CO}_{2}}$ and trace elements, respectively.

\section{References}

Aggarwal, J.K., Palmer, M.R., Bullen, T.D., Arnosson, S., Ragnarsdottir, K.V., 2000. The boron isotope systematic of Icelandic geothermal waters: 1 . Meteoric water charged systems. Geochim. Cosmochim. Acta 64, 579-585.

Aiuppa, A., Avino, R., Brusca, L., Caliro, S., Chiodini, G., D'Alessandro, W., Favara, R. Federico, C., Ginevra, W., Inguaggiato, S., Longo, M., Pecoraino, G., Valenza, M., 2006. Mineral control of arsenic content in thermal waters from volcano-hosted hydrothermal systems: insights from Island of Ischia and Phlegrean Fields (Campanian Volcanic Province, Italy). Chem. Geol. 229, 313-330.

Allmendinger, R.W., Jordan, T.E., Kay, S.M., Isacks, B.L., 1997. The evolution of the Altiplano-Puna Plateau of the Central Andes. Annu. Rev, Earth Planet. Sci. 25, 139-174.

Alonso, R.N., 1986. Ocurrencia, Posición Estratigráfica y Génesis de los Depósitos de Boratos de la Puna Argentina. PhD Thesis. Universidad Nacional de Salta, Salta Argentina.

Alonso, R.N., 1999. Boratos terciarios de la Puna. In: Zappettini, E.O. (Ed.), Recursos Minerales de la República Argentina. SEGEMAR, 35, pp. 1779-1826.

Arnorsson, S., 1983. Chemical equilibria in Icelandic geothermal systems-implications for chemical geothermometry investigations. Geothermics 12 (2-3), 119-128.

Auge, M., Wetten, C., Baudino, G., Bonorino, G., Gianni, R., González, N., Tineo, A., 2006 Hidrogeología de Argentina. Bol. Geol. Min. 117 (1), 7-23.

Bahlburg, H., 1998. The geochemistry and provenance of Ordovician turbidites in the Argentine Puna. Geol. Soc. Lond. Spec. Publ. 142 (1), 127-142

Barnes, I., Downes, C.T., Hulston, R.J., 1978. Warm Springs South Island, New Zealand, and their potentials to yield laumotite. Am. J. Sci. 278, 1412-1427.

Bencini, A., 1985. Applicabilità del metodo dell'Azometina-H alla determinazione del Boro nelle acque naturali. Rend. Soc. Ital. Mineral. Petrol. 40, 311-316.

Bencini, A., Martini, M., 1979. Variazioni del contenuto di silice nelle acque freatiche di vulcano. Rend. Soc. Ital. Mineral. Petrol. 35, 639-646.

Brodtkorb, M.K., Ramos, V., Barbieri, M., Ametrano, S., 1982. The evaporitic celestite-barite deposits of Neuquen, Argentina. Mineral. Deposita 17, 423-436.

Brondi, M., Dall'Aglio, M., Vitrani, F., 1973. Lithium as pathfinder element in the large scale hydrothermal exploration for hydrothermal systems. Geothermics 2, 142-153.

Cabrera, A.P., Caffe, P.J., 2009. The Cerro Morado Andesites: volcanic history and eruptive styles of a mafic volcanic field from northern Puna, Argentina. J. S. Am. Earth Sci. 28 113-131.

Caffe, P.J., Trumbull, R.B., Coira, B.L., Romer, R.L., 2002. Petrogenesis of early Neogene magmatism in the northern Puna; implications for magma genesis and crustal processes in the Central Andean plateau. J. Petrol. 43, 907-942.

Caffe, P.J., Soler, M.M., Rodríguez, G., Coira, B., Onoe, A.T., 2005. El Complejo Volcanico Pairique. Volcanismo Peraluminoso Tipo S en los Andes Centrales del Sur. Fin. Proc. XVI Argentinean Geological Congress, 19-23 September, La Plata, Argentina pp. 643-650.

Caffe, P.J., Soler, M.M., Coira, B., Cabrera, A., Flores, P., 2007. Estratigrafía y centros eruptivos de la región de Pairique, Puna Jujena. Rev. Asoc. Geol. Argent. 62, 242-246.

Caffe, P.J., Soler, M.M., Coira, B.L., Onoe, A.T., Cordani, U.G., 2008. The Granada ignimbrite: compound pyroclastic unit, and its relationship with Upper Miocene caldera volcanism in the northern Puna. J. S. Am. Earth Sci. 25, 464-484.

Caffe, P.J., Maro, G., Presta, J.F., Flores, P.I., Peralta, Y., 2012. Neogene Monogenetic Volcanoes From the Northern Puna of Argentina, Central Andean Plateau. Fin. Proc. IV Int. Maar Conference, Multidisciplinary Congress on Monogenetic Volcanism, 20-24 February, Auckland, New Zealand pp. 19-20.

Cinti, D., Poncia, P.P., Brusca, L., Tassi, F., Quattrocchi, F., Vaselli, O., 2015. Spatial distribution of arsenic, uranium and vanadium in the volcanic-sedimentary aquifers of the Vicano-Cimino Volcanic District (Central Italy). Geol. Explor. 152, 123-133.

Chmielowski, J., Zandt, G., Haberland, C., 1999. The central Andean Altiplano-Puna magma body. Geophys. Res. Lett. 26, 783-786.

Chiodini, G., 1996. Gases dissolved in groundwaters: analytical methods and examples of applications in central Italy. In: Marini, L., Ottonello, G. (Eds.), Rome Seminar on Environmental Geochemistry. Pacini Editore, Castelnuovo d Porto, Rome (Italy), pp. 135-148.

Chiodini, G., Frondini, F., Marini, L., 1995. Theoretical geothermometers and $\mathrm{PCO}_{2}$ indicators for aqueous solutions coming from hydrothermal systems of medium-low temperature hosted in carbonate-evaporite rocks. Application to the thermal springs of the Etruscan Swell, Italy. Appl. Geochem. 10, 337-346.

Coira, B., 2008. Recursos Geotérmicos de Alta Entalpía de la Provincia de Jujuy. Fin. Proc XVII Argentinean Geol. Congress, 7-10 October, Jujuy pp. 563-576.

Coira, B., Caffe, P., 1999. Volcanismo Cenozoico de Puna Norte. Fin. Proc. XIV Argentinean Geological Congress, 19-24 September, Salta pp. 371-386.

Coira, B., Pérez, B., 2002. Peperitic textures of Ordovician dacitic synsedimentary intrusions in Argentina's Puna Highland: clues to emplacement conditions. J. Volcanol. Geotherm. Res. 114 (1), 165-180.
Coira, B., Kay, S.M., Viramonte, J. 1993. Upper Cenozoic magmatic evolution of the Argentine Puna - a model for changing subduction geometry. Int. Geol. Rev. 35, 677-720.

Coira, B., Caffe, P., Mahlburg Kay, S., Diaz, A., Ramírez, A., 1996. Complejo Volcánico de Vilama - Sistema Caldérico del Cenozoico Superior en Puna, Jujuy. Fin. Proc. XIII Argentinean Geol. Congress, 13-18 October, Buenos Aires pp. 603-620.

Coira, B., Caffe, P.J., Ramírez, A., Chayle, W., Díaz, A., Rosas, S.A., Pérez, A., Pérez, E.M.B., Orosco, O., Martínez, M., 2004. Geol. Sheet 2366-I Mina Pirquitas (1:250.000). SEGEMAR 269, 1-123.

Coira, B., Mahlburg Kay, S., Caffe, P.J., 2008. Magmatismo Neógeno Tardío de la Puna norte, in Geología y Recursos Naturales de la Provincia de Jujuy. Fin. Proc. XVII Argentinean Geological Congress, 7-10 October, Jujuy pp. 313-321.

Coira, B., Kirschbaum, A., Hongn, F., Pérez, B., Menegatti, N., 2009. Basic magmatism in northeastern Puna, Argentina: chemical composition and tectonic setting in the Ordovician back-arc. J. S. Am. Earth Sci. 28 (4), 374-382.

Coleman, M.L., Sheperd, T.J., Rouse, J.E., Moore, G.R., 1982. Reduction of water with zinc for hydrogen isotope analysis. Anal. Chem. 54, 993-995.

Coutand, I., Cobbold, P.R., Urreiztieta, M., Gautier, P., Chauvin, A., Gapais, D., Rossello, E.A., Lopez, O., 2001. Style and history of Andean deformation, Puna Plateau, NW Argentina. Tectonics 20, 210-234

D'Amore, F., Panichi, C., 1980. Evaluation of deep temperatures of hydrothermal systems by a new gas geothermometer. Geochim. Cosmochim. Acta 44 (3), 549-556.

Davis, S.N., Cecil, L.D., Zreda, M., Moysey, S., 2001. Chlorine-36, bromide, and the origin of spring water. Chem. Geol. 179, 3-16.

de Silva, S.L., 1989. Altiplano-Puna volcanic complex of the central Andes. Geology 17, 1102-1106.

de Silva, S.L., Zandt, G., Trumball, R., Viramonte, J.G., Salas, G., Jiménez, N., 2006. Large ignimbrite eruptions and volcano-tectonic depressions in the Central Andes: a thermomechanical perspective. In: Troise, C., De Natale, G., Kilburn, C.R.J. (Eds.), Mechanisms of Activity and Unrest at Large Calderas. Geol. Soc. London Spec. Publ Vol. 269, pp. 47-63.

del Papa, C., Hongn, F., Powell, J., Payrola, P., Do Campo, M., Strecker, M.R., Petrinovic, I., Schmitt, A.K., Pereyra, R., 2013. Middle Eocene-Oligocene broken foreland evolution in the Andean Calchaquí Valley, NW Argentina: insights from stratigraphic, structural and provenance studies. Basin Res. 25, 574-593.

Epstein, S., Mayeda, T.K., 1953. Variation of the ${ }^{18} \mathrm{O} /{ }^{16} \mathrm{O}$ ratio in natural waters. Geochim. Cosmochim. Acta 4, 213-224.

Evans, W.C., White, L.D., Rapp, J.B., 1998. Geochemistry of some gases in hydrothermal fluids from the southern San Juan de Fuca ridge. J. Geophys. Res. 15, 305-313.

Fontes, J.C., Matray, J.M., 1993. Geochemistry and origin of formation brines from the Paris Basin, France. Chem. Geol. 109, 177-200.

Fournier, R.O., 1977. Chemical geothermometers and mixing models for geothermal systems. Geothermics 5, 41-50.

Fracchia, D., 2009. Volcanismo Postcolapso de la Caldera Vilama, Mioceno Superior, Puna Argentino-Boliviana: Mecanismos Eruptivos y Petrogénesis. PhD Thesis. Facultad de Ciencias Naturales y Museo, Universidad Nacional de La Plata, La Plata, Argentina.

Garreaud, R.D., 2009. The Andes climate and weather. Adv. Geosci. 22, 3-11.

Garreaud, R.D., Molina, A., Farias, M., 2010. Andean uplift, ocean cooling and Atacama hyperaridity: a climate modeling perspective. Earth Planet. Sci. Lett. 292, 39-50.

Garrett, D.E., 2004. Handbook of Lithium and Natural Calcium Chloride - Their Deposits, Processing, Uses and Properties. first ed. Elsevier Academic Press, Amsterdam, Boston, p. 476.

Giggenbach, W.F., 1987. Redox processes governing the chemistry of fumarolic gas discharges from White Island, New Zealand. Appl. Geochem. 2 (2), 143-161.

Giggenbach, W.F., 1988. Geothermal solute equilibria. Derivation of Na-K-Mg-Ca geoindicators. Geochim. Cosmochim. Acta 52 (12), 2749-2765.

Giggenbach, W.F., 1991. Chemical techniques in geothermal exploration. In: D'Amore, F. (Ed.), Application of Geochemistry in Geothermal Reservoir Development. UNITAR, pp. 119-144.

Giggenbach, W.F., 1992. Isotopic shifts in waters from geothermal and volcanic systems along margins, and their origin. Earth Planet. Sci. Lett. 113, 495-510.

Giordano, G., Pinton, A., Cianfarra, P., Baez, W., Chiodi, A., Viramonte, J., Norini, G. Groppelli, G., 2013. Structural control on geothermal circulation in the Cerro Tuzgle-Tocomar geothermal volcanic area (Puna plateau, Argentina). J. Volcanol. Geotherm. Res. 249, 77-94.

Göb, S., Loges, A., Nolde, N., Bau, M., Jacob, D.E., Markl, G., 2013. Major and trace element compositions (including REE) of mineral, thermal, mine and surface waters in SW Germany and implications for water-rock interaction. Appl. Geochem. 33, 127-152.

Heidorn, R., 2002. Geodynamic Evolution of the Central Andean Backarc With Respect to Tertiary Epithermal Mineralization. PhD thesis. University of Salzburg, Austria, p. 111.

Helvaci, C., Alonso, R.N., 2000. Borate deposits of Turkey and Argenitna: a summary and goelogical comparison. J. Earth Sci. 9, 1-27.

Hilton, D.R., Fischer, T.P., Marty, B., 2002. Noble gases and volatile recycling at subduction zones. Rev. Mineral. Geochem. 47, 319-370.

Hoke, G.D., Aranibar, J.N., Viale, M., Araneo, D.C., Llano, C., 2013. Seasonal moisture sources and the isotopic composition of precipitation, rivers, and carbonates across the Andes at $32.5-35.5^{\circ} \mathrm{S}$. Geochem. Geophys. Geosyst. 14 (4), 962-978.

Hoefs, J., 2009. Stable Isotope Chemistry. sixth ed. Springer, Berlin, New York, p. 260

Horita, J., Wesolowski, D.J., 1994. Liquid-vapor fractionation of oxygen and hydrogen isotopes of water from the freezing to the critical temperature. Geochim. Cosmochim. Acta 58 (16), 3425-3437.

Inguaggiato, S., Rizzo, A., 2004. Dissolved helium isotope ratios in ground-waters: a new technique based on gas-water re-equilibration and its application to Stromboli volcanic system. Appl. Geochem. 19 (5), 665-673.

Javoy, M., Pineau, F., Allegre, C.J., 1982. Carbon geodynamic cycle. Nature 300 (5888), $171-173$. 
Kaasalainen, H., Stefánsson, A., 2012. The chemistry of trace elements in surface geothermal waters and steam, Iceland. Chem. Geol. 330, 60-85.

Kay, S.M., Coira, B., Caffe, P.J.Y., Chen, C.-H., 2010. Regional chemical diversity, crustal and mantle sources and evolution of central Andean Puna plateau ignimbrites. J. Volcanol. Geotherm. Res. 198, 81-111.

Langelier, W.F., Ludwig, H.F., 1942. Graphical methods for indicating the mineral character of natural waters. JAWWA 34, 335.

Lopez Steinmetz, R.L., 2016. Lithium-and boron-bearing brines in the Central Andes: exploring hydrofacies on the eastern Puna plateau between $23^{\circ}$ and $23^{\circ} 30^{\prime} \mathrm{S}$. Mineral. Deposita 1-16.

Mamyrin, B.A., Tolstikhin, I.N., 1984. Helium Isotopes in Nature. Elsevier, Amsterdam.

Marquillas, R.A., del Papa, C., Sabino, I.F., 2005. Sedimentary aspects and paleoenvironmental evolution of a rift basin: Salta Group (Cretaceous-Paleogene), northwestern Argentina. Int. J. Earth Sci. 94, 94-113.

Marty, B., Jambon, A., 1987. C ${ }^{3}$ He fluxes from the solid Earth: implications for carbon geodynamics. Earth Planet. Sci. Lett. 83, 16-26.

O'Leary, M.H., 1988. Carbon isotopes in photosynthesis. Bioscience 38, 328-336.

Ohmoto, H., Goldhaber, M.B., 1997. Sulfur and carbon isotopes. In: Barnes, H.L. (Ed.), Geochemistry of Hydrothermal Ore Deposits. John Wiley \& Sons, pp. 517-611.

Ozima, M., Podosek, F.A., 1983. Nobel Gas Geochemistry. Cambridge Univ. Press, Cambridge, UK, pp. 39-41.

Petrinovic, I.A., Riller, U., Alvarado, G., Brod, A., Arnosio, J., 2006. Bimodal volcanism in a tectonic transfer zone: evidence for tectonically controlled magmatism in the southern Central Andes, NW Argentina. J. Volcanol. Geotherm. Res. 152, 240-252.

Pesce, A., 2008. El recurso Geotérmico en la Región del Ramal, Provincia de Jujuy. Fin. Proc. XVII Argentinean Geol. Congress, 7-10 October, Jujuy pp. 577-585.

Poreda, R.J., Craig, H., 1989. Helium isotope ratios in circum-Pacific volcanic arcs. Nature 338, 473-478.

Ramírez, A., 1997. Magmatismo y Mineralizaciones Asociadas en los Cerros CaucaniSolterío. Master Thesis. Universidad Nacional de Salta, Salta, Argentina.

Risacher, F., Fritz, B., Hauser, A., 2011. Origin of components in Chilean thermal waters. J. S. Am. Earth Sci. 31, 153-170.

Rodrıguez, G.A., 1997. Manifestaciones Minerales Asociadas al Volcanismo Cenozoico en Cerro Colorado-Orosmayo (Dpto Rinconada - Prov. de Jujuy). Master Thesis. Universidad Nacional de Córdoba, Córdoba, Argentina.

Rollinson, H., 1993. Using Geochemical Data. Longman, London, UK, p. 352.

Salisbury, M.J., Jicha, B.R., de Silva, S.L., Singer, B.S., Jiménez, N.C., Ort, M.H., 2011. ${ }^{40} \mathrm{Ar} /{ }^{39} \mathrm{Ar}$ chronostratigraphy of Altiplano-Puna volcanic complex ignimbrites reveals the development of a major magmatic province. Geol. Soc. Am. Bull. 123, 821-840.

Schoell, M., 1980. The hydrogen and carbon isotopic composition of methane from natural gases of various origins. Geochim. Cosmochim. Acta 44, 649-661.

Schoell, M., 1988. Multiple origins of methane in the Earth. Chem. Geol. 71, 1-10.

Scott, S.D., 1997. Submarine hydrothermal systems and deposits. In: Barnes, H.L. (Ed.), Geochemistry of Hydrothermal Ore Deposits. Wiley, New York, pp. 797-935.
Seggiaro, R., Becchio, R.Y., Zappettini, E., 2007. Hoja Geológica Susques 2366-III. Escala $1:$ 250.000. Instituto de Geología y RECURSOS minerales (IGRM). SEGEMAR, Argentina.

Seggiaro, R., Guzmán, S., Martí, J., Montero, C., López, E., 2014. Stratigraphy of the Coranzulí caldera. STRATI 2013. Springer International Publishing, 1273, p. 1269.

Soler, M.M., Caffe, P.J., Coira, B.L., Onoe, A.T., Kay, S.M., 2007. Geology of the Vilama caldera: a new interpretation of a large-scale explosive event in the Central Andean plateau during the Upper Miocene. J. Volcanol. Geotherm. Res. 164 (1), 27-53.

Soler, M., Iradi, P., Pérez, C., Hoyos, M., 2008. Principales Aspectos de la Geología, Recursos y Minado de Mina Pirquitas. Fin. Proc. XVII Argentinean Geol. Congress, 7-10 October, Jujuy pp. 343-349.

Taran, Y.A., Pokrovsky, B., Doubik, Y.M., 1989. Deuterium and oxygen-18 in fumarolic steam and amphiboles from some Kamchatka volcanoes: "andesitic waters". Doklady Akademiinauk SSSR 304, 440-443.

Taran, Y.A., Giggenbach, W.F., 2003. Geochemistry of light hydrocarbons in subductionrelated volcanic and hydrothermal fluids. Soc. Econ. Geol. 10, 61-74.

Truesdell, A.H., Hulston, J.R., 1980. Isotopic evidence on environments of geothermal systems. In: Fritz, P. (Ed.), Handbook of Environmental Isotopes Geochemistry. The Terrestrial Environment A Vol. 1. Elsevier, Amsterdam, pp. 179-226.

Vaselli, O., Tassi, F., Montegrossi, G., Capaccioni, B., Giannini, L., 2006. Sampling and analysis of volcanic gases. Acta Vulcanol. 18, 65-76.

Ward, K.M., Zandt, G., Beck, S.L., Christensen, D.H., McFarlin, H., 2014. Seismic imaging of the magmatic underpinnings beneath the Altiplano-Puna volcanic complex from the joint inversion of surface wave dispersion and receiver functions. Earth Planet. Sci. Lett. 404, 43-53.

Warren, J.K., 2010. Evaporites through time: tectonic, climatic and eustatic controls in marine and nonmarine deposits. Earth-Sci. Rev. 98, 217-268.

Whitfield, M., 1978. Activity coefficients in natural waters. In: Pytkowicz, R.M. (Ed.), Activity Coefficients in Electrolyte Solutions. CRC Press, Boca Raton, Florida pp. 153-300.

Whiticar, M.J., Faber, E., Schoell, M., 1986. Biogenic methane formation in marine and freshwater environments: $\mathrm{CO}_{2}$ reduction vs. acetate fermentation - isotopic evidence. Geochim. Cosmochim. Acta 50, 693-709.

Whiticar, M.J., 1999. Carbon and hydrogen isotope systematic of bacterial formation and oxidation of methane. Chem. Geol. 161, 291-314.

Wilhelm, E., Battino, R., Wilcock, R.J., 1977. Low-pressure solubility of gases in liquid water. Chem. Rev. 77 (2), 219-262.

Wilson, N., Webster-Brown, J., Brown, K., 2012. The behaviour of antimony released from surface geothermal features in New Zealand. J. Volcanol. Geotherm. Res. 247-248 $158-167$.

Zandt, G., Leidig, M., Chmielowski, J., Baumont, D., Yuan, X., 2003. Seismic detection and characterization of the Altiplano-Puna magma body, Central Andes. Pure Appl. Geophys. 160, 789-807.

Zhang, J., Quay, P.D., Wilbur, D.O., 1995. Carbon isotope fractionation during gas-water exchange and dissolution of $\mathrm{CO}_{2}$. Geochim. Cosmochim. Acta 59, 107-114. 